NBER WORKING PAPER SERIES

DOES PARTISAN CONFLICT DETER FDI INFLOWS TO THE US?

\author{
Marina Azzimonti \\ Working Paper 22336 \\ http://www.nber.org/papers/w22336 \\ NATIONAL BUREAU OF ECONOMIC RESEARCH \\ 1050 Massachusetts Avenue \\ Cambridge, MA 02138 \\ June 2016, Revised May 2018
}

The views expressed herein are those of the author and do not necessarily reflect the views of the National Bureau of Economic Research.

NBER working papers are circulated for discussion and comment purposes. They have not been peer-reviewed or been subject to the review by the NBER Board of Directors that accompanies official NBER publications.

(C) 2016 by Marina Azzimonti. All rights reserved. Short sections of text, not to exceed two paragraphs, may be quoted without explicit permission provided that full credit, including ()$^{\circ}$ notice, is given to the source. 
Does Partisan Conflict Deter FDI Inflows to the US?

Marina Azzimonti

NBER Working Paper No. 22336

June 2016, Revised May 2018

JEL No. E62,F21,F3,H3

\section{$\underline{\text { ABSTRACT }}$}

I analyze how partisan conflict about trade policy affects foreign direct investment flows to the US using a novel indicator, the Trade Partisan Conflict Index (TPCI). Partisan conflict is relevant for the evolution of cross-border capital flows because the expected returns on investment projects are less predictable when the timing, size, and composition of trade policy is uncertain. The trade partisan conflict index tracks the evolution of political disagreement among policymakers on topics such as tariffs, subsidies, and trade agreements as reported by the media. Using data from 1985 to 2016, I show that an innovation of the PCI is associated with a significant decline in FDI flows to the US. The effect is also present when disaggregated (annual) data from a panel of parent countries is considered instead.

Marina Azzimonti

Economics Department

Stony Brook University

100 Nicolls Road

Stony Brook, NY 11794

and NBER

marina.azzimonti@gmail.com 


\title{
Does partisan conflict deter FDI inflows to the US?
}

\author{
Marina Azzimonti*
}

May, 2018

\begin{abstract}
I analyze how partisan conflict about trade policy affects foreign direct investment flows to the US using a novel indicator, the Trade Partisan Conflict Index (TPCI). Partisan conflict is relevant for the evolution of cross-border capital flows because the expected returns on investment projects are less predictable when the timing, size, and composition of trade policy is uncertain. The trade partisan conflict index tracks the evolution of political disagreement among policymakers on topics such as tariffs, subsidies, and trade agreements as reported by the media. Using data from 1985 to 2016, I show that an innovation of the PCI is associated with a significant decline in FDI flows to the US. The effect is also present when disaggregated (annual) data from a panel of parent countries is considered instead.
\end{abstract}

JEL Classification: F3, E3, H3, E6.

\section{Introduction}

Direct investment positions in the US (as percentages of GDP) have grown considerably since the 1980s, as shown in Figure 1. Moreover, direct investment flows constitute a considerable fraction of cross-border transactions. For example, U.S. direct investment flows in 2013 composed about half of the total U.S. net acquisition of foreign financial assets, and foreign direct investment flows were about 20 percent of the total foreign net acquisition of U.S. financial assets. ${ }^{1}$ There is an extensive empirical literature studying the determinants of capital inflows, that has mostly centered on macroeconomic conditions, monetary and exchange rate policy, geographic proximity, and institutional factors (see Faeth, 2009 for a survey of the literature). In this paper, I focus on political disagreement instead. More specifically, I study whether partisan conflict on trade policy deters foreign direct investment.

\footnotetext{
${ }^{*}$ Stony Brook University and NBER.

${ }^{1}$ See Table F.106 of the September 2014 publication of the Federal Reserve Board Statistical Release Z.1, "Financial Accounts of the United States."
} 


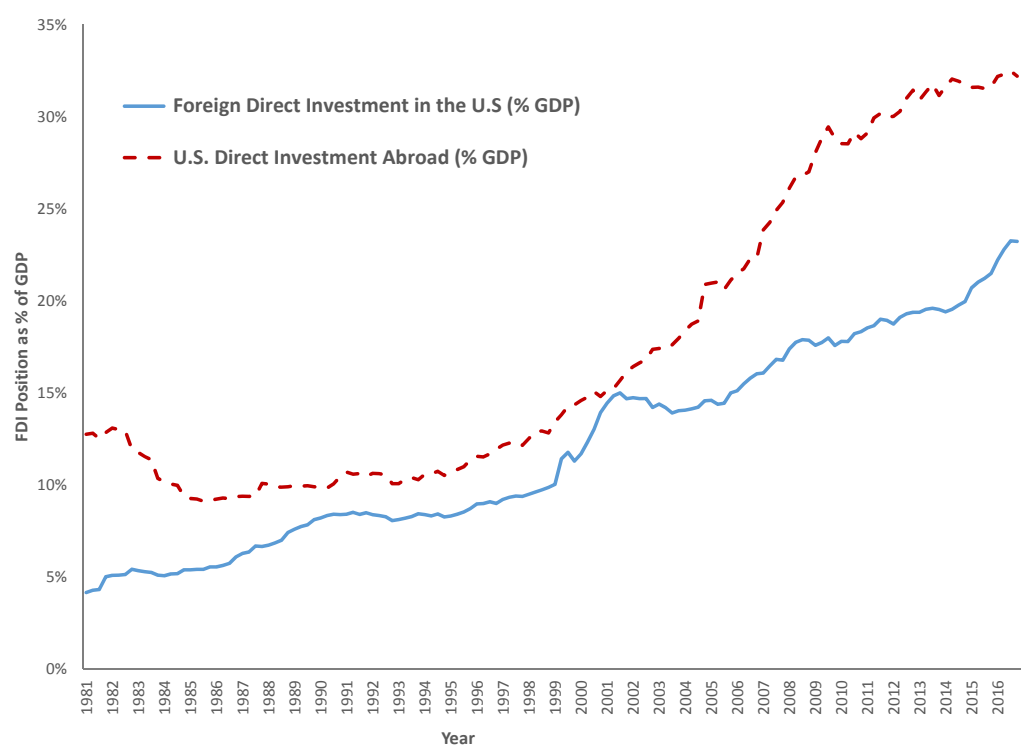

Figure 1: Direct Investment Positions as \% of US GDP, 1981:Q1 to 2016:Q4.

Source: FRED database (Federal Reserve Bank of St. Louis). For more details see Appendix 6.4.

Partisan conflict is relevant for the evolution of foreign direct investment flows to the US because the expected returns of investment projects become less predictable when policy is uncertain. Foreign direct investors typically have a long time horizon when operating abroad. They are less informed about the policy environment and may be treated differently than domestic investors (Battacharya, Galpin, and Haslem 2007). Moreover, FDI cannot be easily reversed without paying large costs (Rivoli and Salorio, 1996). Hence, forward-looking foreign investors must be constantly anticipating how changes in trade policy could affect the expected returns of their investments and/or their barriers to enter and exit the US market.

Following the large contraction in cross border investment flows during the 2008 Financial Crisis and its unusually slow recovery from the Great Recession (see Figure 2), together with the high levels of uncertainty caused by the political climate in the US, the detrimental effects of policy uncertainty gained interest as a possible explanation (Julio and Yook, 2016). ${ }^{2}$ The standard approach in this literature uses the timing of elections to measure variations in policy uncertainty (see Durnev, 2010 and Julio and Yook, 2012, 2016). While this provides a quasinatural experiment in a panel of countries, it may confound the effects of uncertainty with those that naturally arise under the 'political business cycle' (Nordhaus, 1975). According

\footnotetext{
${ }^{2}$ Even though FDI net inflows have been positive for most of the sample, we see a large disinvestment in the first quarter of 2014 (of around 1.7\% of GDP). An OECD report on FDI published on December 2014 states that 'The drop in FDI in the first quarter was mainly due to a single deal involving a company in the United Kingdom selling a company in the United States to another US company causing both outward FDI from the United Kingdom and inward FDI to the United States to fall.' Note that negative values of FDIUS represent net inflows where divestment was greater than investment in a given quarter. For more details, see https://www.oecd.org/investment/FDI-in-Figures-Dec-2014.pdf
} 


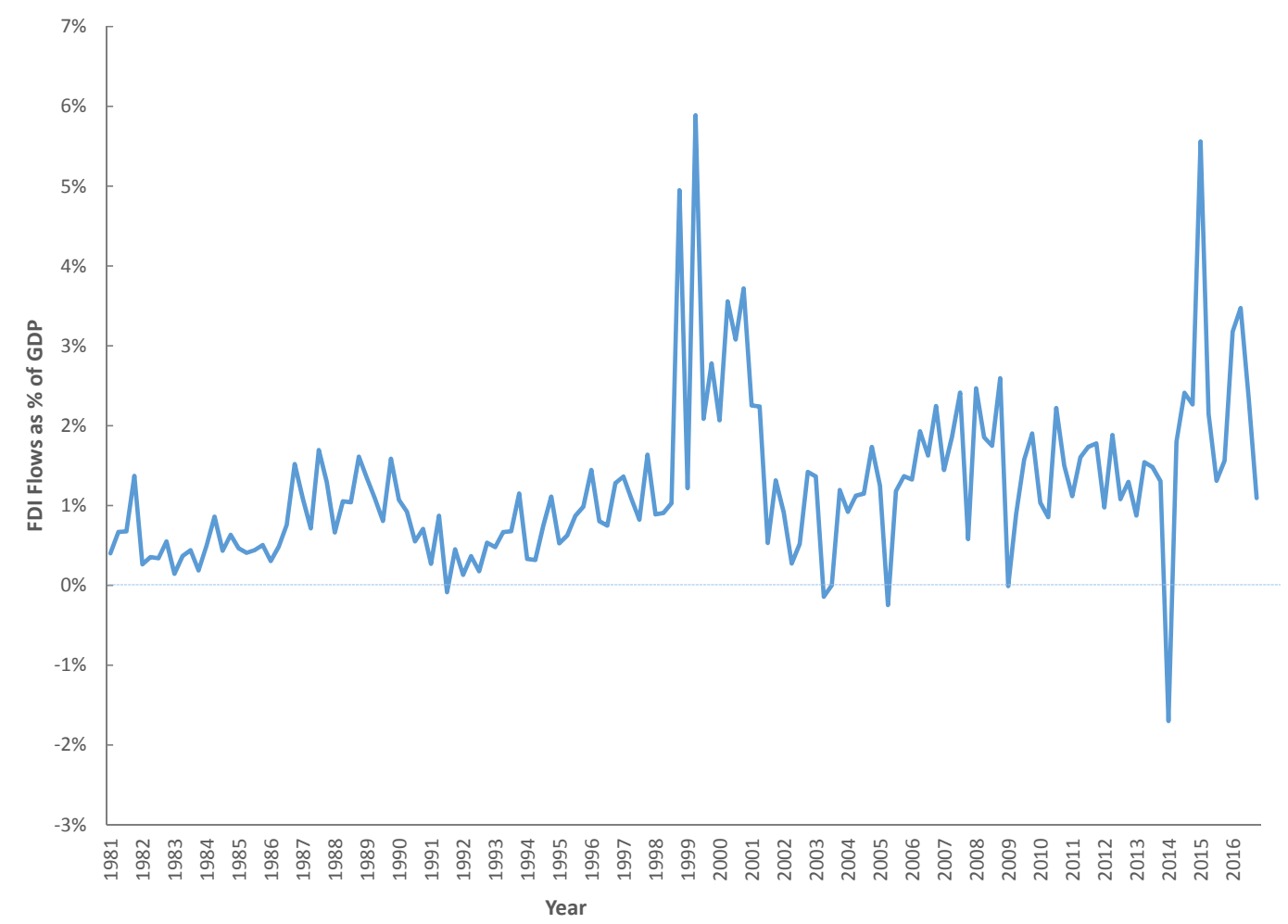

Figure 2: Foreign Direct Investment Flows as a \% of GDP (quarterly), 1981:Q1 to 2016:Q4.

Source: FRED database (Federal Reserve Bank of St. Louis). For more details see Appendix 6.4.

to the original political business cycle theory, policymakers have incentives to stimulate the economy prior to an election. If investors are naive, they would increase investment in response. If they are forward-looking, as suggested by more recent theories (see Canes-Wron Park, 2011), they may reduce investment in expectation of higher taxes used to pay for the stimulus policy after elections take place. Regardless of the direction, this potential response makes it difficult to disentangle the effect of uncertainty from that of the political cycle around elections. Moreover, the political climate may also affect FDI in off-election periods. To the extent policymakers disagree on the details trade agreement (such as NAFTA) or protectionist policies (such as an increase in steel tariffs), uncertainty over the policy to be implemented can affect the behavior of foreign investors. In this paper, in addition to using the timing of elections, I also consider an important underlying cause of political uncertainty: the degree of conflict between actors determining policy itself. To that end, I develop the Trade Partisan Conflict Index (TPCI), which tracks the frequency of newspaper articles reporting political disagreement on trade policy in a given month. Higher index values indicate greater conflict among political parties, Congress, and the President. The index rises not only when elections take place (and trade policy is discussed during the campaign), but also around well-known policy debates such as those surrounding international trade agreements such as GATT, 
NAFTA, and TPP, as well as the implementation of barriers to imports (such as the steel import quota of 1999), and measures that may affect the returns to cross-country capital flows. Hence, it is a complementary measure of political uncertainty to the timing of elections or political turnover. Because it is measured at the monthly level, it allows us to identify the effects of uncertainty at shorter frequencies than alternative uncertainty proxies. Relative to other similar measures of uncertainty, such as the Partisan Conflict Index (PCI) developed by Azzimonti (2018) or the Economic Policy Uncertainty (EPU) index developed by Baker, Bloom, and Davis (2015), it has the advantage of capturing uncertainty about information that is potentially more relevant for FDI, namely trade policy. Finally, since the measure is based on political disagreement as reported by the media, it is potentially a good summary statistic of the information used by foreign investors to make decisions and update their expectations. $^{3}$

The first empirical model aims at estimating the effect of TPCI on foreign direct investment from the rest of the world as a percentage of the existing position at the beginning of a given quarter. I include standard control variables, such as trade openness, changes in the exchange rate, the level of inflation, the growth rate of GDP, the federal funds rate, and whether Presidential elections are held. I find that a one standard deviation increase in PCI at a given quarter results in about 0.127 standard-deviation decline in investment flows (as percentage of the position in the country) in the following quarter. This corresponds to about a $8.9 \%$ decline in FDI flows from it sample mean. Since TPCI may not be the only source of political uncertainty, I also consider the effects of PCI and EPU together with TPCI in an augmented model. I find that the result is robust to introducing these variables. Finally, I also consider alternative measures of expectations typically used in the literature to reduce potential omitted variable bias (such as consumer confidence and predictions regarding GDP growth), but these do not significantly alter the results.

I also study investment flows to the US disaggregated by country of origin (e.g parent country). ${ }^{4}$ I consider a panel of 38 countries with annual data over the period 1985-2016. The multi-country model specification includes country specific control variables (such as the growth rate of the parent country, its inflation rate and changes in the degree of trade openness), pair-specific variables (such as changes in the bilateral exchange rate and bilateral trade with the US), US-centric variables (those used in the aggregate specification above),

\footnotetext{
${ }^{3}$ See Azzimonti (2017) for a theoretical model linking partisan conflict to political uncertainty. Moderate levels of partisan conflict are positively related to economic policy uncertainty. There is a threshold point in which additional increases in PCI actually reduce uncertainty about policy (e.g. the relationship between PCI and EPU is inverted u-shaped). Investors still react negatively to gridlock because they expect the government to choose inefficient policies when partisan conflict is high (by, for example, not reacting soon enough to negative shocks). Empirically, neither the PCI nor the TPCI allow us to disentangle the effects of gridlock (which can potentially actually be positive in some cases) from those of uncertainty. Developing separate indexes is an interesting avenue of future research.

${ }^{4}$ Reverse causality is typically an issue in models trying to address the effects of political uncertainty on domestic investment, as policymakers may disagree about economic policy (which implies high levels of the PCI) in periods where investment is low because of its effects on the government budget. This is less likely to be a problem with FDI, as foreign investment does not significantly affect government revenues. It is even less likely that changes in foreign investment from a specific parent country would consistently affect the aggregate level of disagreement across policymakers in the US.
} 
and country specific fixed-effects (to control for time invariant country characteristics such as geographic and language proximity). I find that a one-standard deviation increase in PCI is associated, on average, with a 0.04 standard-deviation decline in FDI flows as a percentage of the positions in the US in a given year.

Finally, I also consider whether countries in different geographical regions or with different degrees of economic development have an heterogeneous response to changes in the trade partisan conflict index. I find that Canada and Mexico (both included in the NAFTA agreement) have a smaller reaction than other countries to increases in TPCI. Among those other countries, Middle-Eastern, East Asian, and Latin American countries have a stronger reaction to rises in TPCI than Canada and Mexico. This is not the case for European and South-East Asian countries. Finally, I find that emerging economies (e.g. those not in the OECD) reduce FDI inflows to the US by a larger amount when TPCI rises than OECD countries do.

Related Literature The result is consistent with predictions from the theoretical literature studying the effects of policy uncertainty on aggregate investment (Bernanke, 1983; Bloom, 2009; Fernández-Villaverde and Rubio-Ramírez, 2010; Stokey, 2016; Bloom, Bond, and Van Reenen, 2007; Pindyck and Solimano, 1993). These theories suggest that in periods of high variability of fiscal policy, economic agents delay hiring, investment, and production decisions. Canes-Wrone and Park (2011) connect increases in policy uncertainty with the electoral cycle, arguing that agents have incentives to delay decisions subject to large reversibility costs before polarized elections. Azzimonti and Talbert (2013) suggest that political disagreement affects economic decisions. They show that polarization increases induce policy uncertainty, causing long run investment to decline. Azzimonti (2017) shows a similar result under imperfect information on the degree of partisan conflict. While most of these studies center on domestic investment, their logic can be easily extended to a framework of foreign direct investment facing uncertainty about trade policy. Rodrik (1991) models FDI choices explicitly under political uncertainty in an environment where agents face uncertainty about the success of a political reform. He shows that foreign investors delay investing until the uncertainty is resolved. This paper contributes to the literature by showing an empirical relationship between political uncertainty, proxied by the TPCI, and foreign direct investment.

This is not the first paper relating political risk to cross-border investment flows empirically. Basi (1963) was among the first to show that political stability is one of the most important determinants of FDI flows. Schneider and Frey (1985) document that political instability significantly affects cross-border flows in developing countries, whereas Singh and Jun (1995) show that political risk affects countries that have attracted high foreign direct investment flows in the past. Wei (2000) finds that the degree of corruption in the parent country reduces FDI flows significantly, Loree and Guisinger (1995) show political stability affects FDI outflows, and Li and Resnick (2003) that democratic institutions affect FDI flows in a panel of countries. ${ }^{5}$ More recently, Busse and Hefeker (2007) show that govern-

\footnotetext{
${ }^{5}$ An exception to these studies is Grosse and Trevino (1996), who find that political risk in the parent country does not effect FDI inflows to the US.
} 
ment stability, internal and external conflict, corruption and ethnic tensions, law and order, democratic accountability of government, and quality of bureaucracy are highly significant determinants of foreign investment inflows. Finally, Julio and Yook (2016) show that FDI flows from US companies to foreign affiliates drop significantly during the period just before an election is held in the destination country.

While this paper complements the results of this literature, there are two main departures. First, I focus on the effect of political uncertainty over trade policy in the US to FDI inflows to the country, whereas most of the literature centered attention on outflows to other countries experiencing uncertainty. Second, I construct a novel indicator of political uncertainty on trade policy constructed from newspaper articles and use to quantify the effects of political disagreement on FDI inflows. The trade partisan conflict index is potentially a more suitable measure of the type of uncertainty faced by foreign investors than proxies previously used in the literature such as political stability (e.g. turnover of the party in power), corruption, economic policy uncertainty, and partisan conflict.

The paper is organized as follows. Section 2 describes how the trade partisan conflict index is constructed. Section 3 analyzes the effects of political uncertainty on the aggregate inflows of foreign direct investment to the US. The empirical model summarized in Section 3.1 and the results described in Section 3.2. Section 4 studies investment flows to the US by country of origin, whereas Section 4.4 allows for the possibility of heterogeneous responses. Section 5 concludes.

\section{Trade Partisan Conflict Index}

The Trade Partisan Conflict Index (TPCI) is a sub-index of the benchmark PCI developed by Azzimonti (2018). ${ }^{6}$ It tracks the degree of political disagreement about trade policy among U.S. policymakers by measuring the frequency of newspaper articles related to the topic in a given month. The benchmark PCI, computed in Azzimonti (2018), quantifies the degree of general disagreement between policymakers (either across party lines or within a party) about fiscal policy and regulation by following coverage of ideologically divisive issues, polarization, gridlock in Congress, and presidential vetoes to legislative measures, among others. The Trade PCI developed in this paper restricts attention to a subset of those articles explicitly discussing foreign trade - agreements and policy—, which are potentially more relevant to foreign investors.

The database from which newspaper information is extracted is Factiva (by Dow Jones) and covers major US newspapers over the interval 1981:Q1-2016:Q1. Table 9 in Appendix 6.1 contains a complete list of sources. The top newspapers included in the search are The Washington Post, The New York Times, Los Angeles Times, Chicago Tribune, The Wall Street Journal, Newsday, The Dallas Morning News, The Boston Globe, and Tampa Bay Times.

The TPCI is computed in a similar way to the benchmark PCI. I first count the number of articles that contain terms related to disagreement between political parties, political actors

\footnotetext{
${ }^{6}$ Monthly PCI series available at the Real-time Data Research Center of the Federal Reserve Bank of Philadelphia.
} 
(e.g. candidates running for office), and branches of government (legislators in Congress, State Governors, and the President) about trade policy in a given month. The articles selected contain at least one keyword in the following three categories: (i) political disagreement, (ii) government, and (iii) trade policy. The specific terms used in each category are listed below

Political Disagreement: standstill, stalemate, gridlock, disagreement, fail to compromise, polarization, polarized, dysfunctional, ideological difference(s), deadlock, budget battle (or fight), filibuster, standoff, veto, vetoes, vetoing, delay /oppose bill. ${ }^{7}$

Government: White House, senate, senator, Capitol, Congress, congressman(woman), party, partisan, Republican, GOP, Democrat, political, politician, legislator, lawmaker, "the President," Appropriation Committee, Finance Committee, Ways and Means Committee, federal government.

Trade Policy: trade policy (policies, act, agreement, or treaty), trade subsidies, import tariff (barrier, duty, or duties), import tariff (or barrier or subsidy, or duty), export tariff (or subsidy), dumping, wto, world trade organization, gatt, Doha round, Uruguay round.

I focus on articles including keywords at the intersection of these three categories, as illustrated by the darker area of Figure 3. The benchmark PCI, on the other hand, includes articles at the intersection of the Political Disagreement and Government sets.

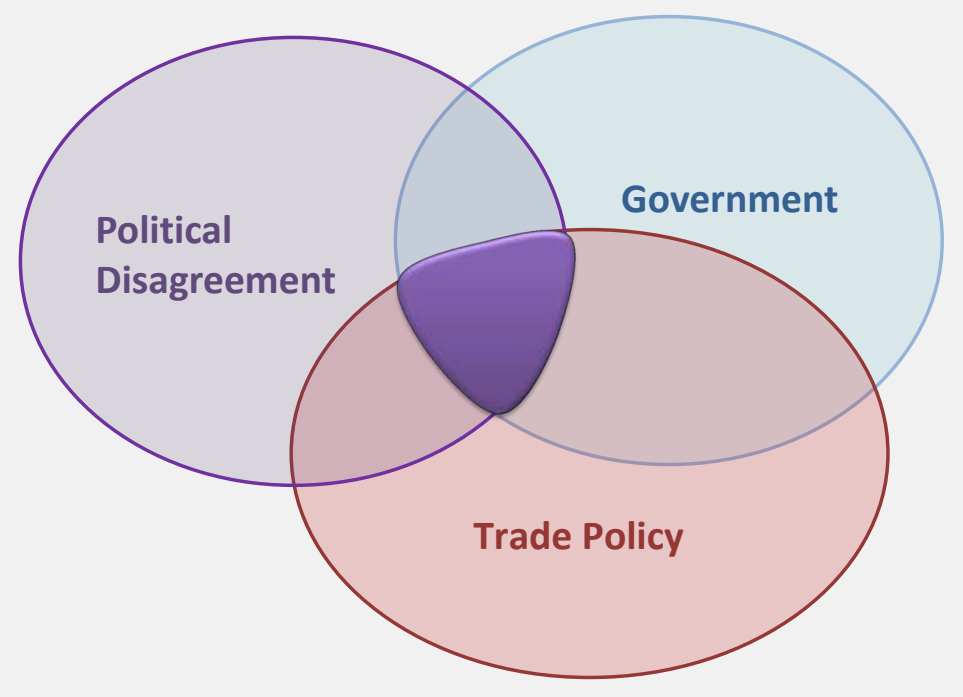

Figure 3: Representation of Boolean search.

In the search, the terms are separated by a small number of words in the article (using the Boolean term 'near' or 'within' 3 to 5 words depending on context). I also apply some specific filters. For example, I restrict the Boolean search to articles related to the US and written

\footnotetext{
${ }^{7}$ In addition, I also search for specific terms related to partisan conflict, such as "partisan divisions," and "divided Congress." Note that the search involves terms related to the political debate (e.g., "fail to compromise"), as well as the outcome of the partisan warfare (e.g. "gridlock" and "filibuster").
} 
in English. ${ }^{8}$ This is the case because it reduces the possibility of capturing news about trade agreements not involving the US (such as the European Union and Brexit). Routine general news, reviews, interviews, etc. are also excluded in order to reduce the incidence of false positives. A comprehensive list of filters applied can be found in Appendix 6.2. Articles with less than 200 words and republished news are excluded (this is standard in the semantics literature, the latter to avoid double-counting). Note that the search is performed on full articles, not just titles or abstracts.

The raw trade partisan conflict count is then divided by the total number of articles in the same newspapers over the same time interval. This number is obtained by counting the number of articles containing the word "today" in a given month. ${ }^{9}$ Finally, the measure is normalized to average 100 in the year 1990. This normalization is without loss of generality, and the year 1990 is chosen to simplify comparisons with the benchmark PCI.

Intuitively, higher index values capture greater conflict among political parties, Congress, and the President on trade-related policies and regulation.

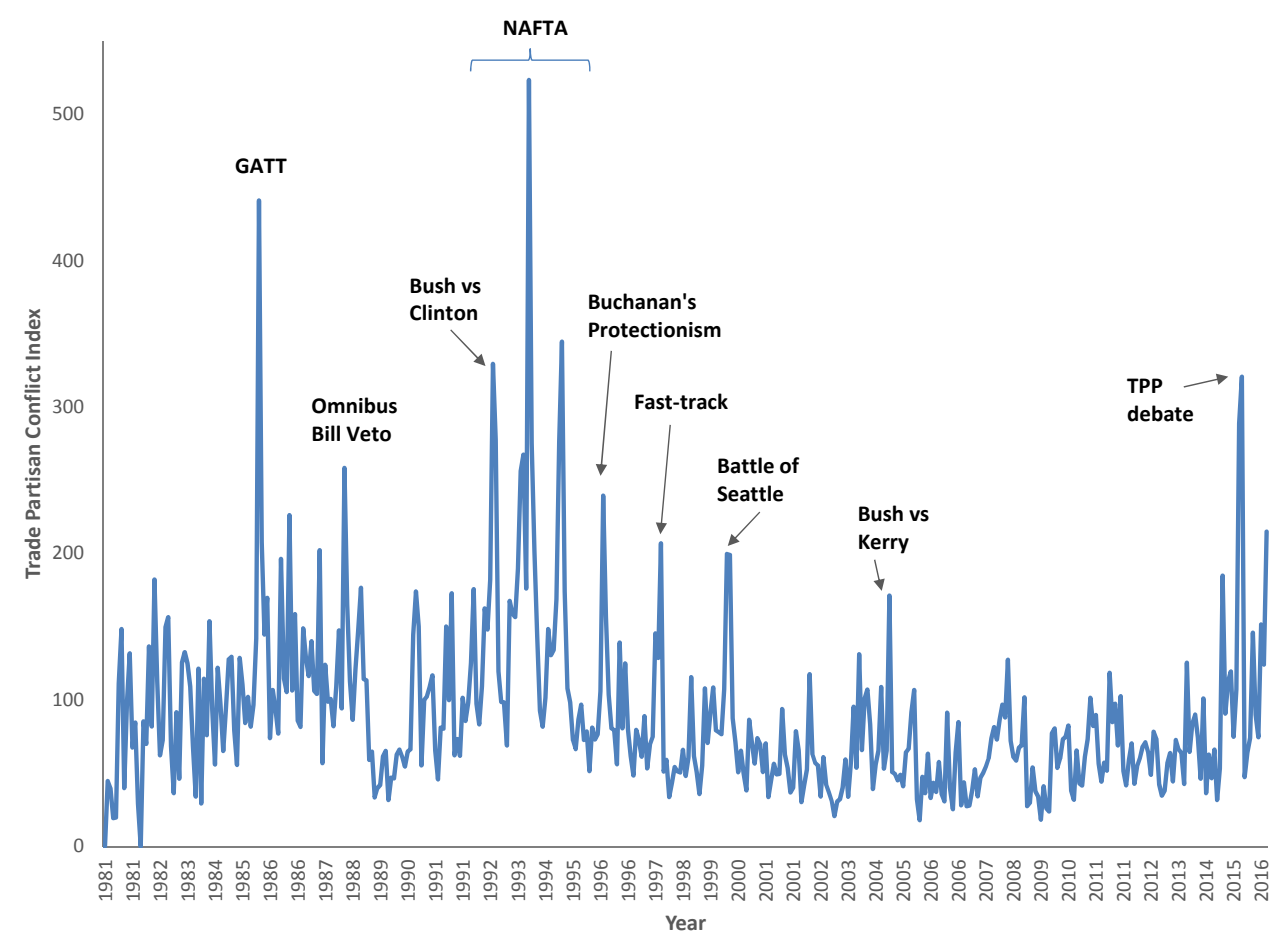

Figure 4: Trade Partisan Conflict Index (monthly, 1990=100).

\footnotetext{
${ }^{8}$ Using a semantic algorithm, Factiva attaches an indexes to the region most related to any given article. I filter out those that are indexed as most related to countries/regions other than the US. This set will therefore include not only articles to the US but also those which have not been coded.

${ }^{9}$ Using the word "the" to count the total number of articles instead causes no noticeable difference in the index.
} 


\subsection{Evolution of Trade PCI}

Figure 4 depicts the evolution of the trade partisan conflict index between 1981 and 2016 obtained from the search. The mean value of TPCI in the sample is 89.9, with a standard deviation of 59. The series has mostly fluctuated around a constant mean throughout the period of study, and exhibited relatively low volatility between 2005 and 2014.

The highest value of 523 was observed on November 1993, month in which the North American Free Trade Agreement (NAFTA) was debated and eventually passed by Congress in the US. The agreement established the world's largest free trade zone at the time, and was signed into a Bill after much consideration and emotional debate in the US House of Representatives. This is illustrated in Appendix 6.3, which contains an excerpt of an LA Times article retrieved from the search in Factiva. It is worth noticing that the large value in the index was obtained despite the fact that NAFTA was not included among the terms of the search.

The second largest spike is observed in September 1985, month in which members of the General Agreements on Tariffs and Trade (GATT) agreed to start negotiations on free trade (which then lead to the Uruguay round starting in 1986). ${ }^{10}$ The final noticeable spike surrounds the Trans-Pacific Partnership (TPP) debate, particularly during June 2015 when the Bill was first rejected by House Democrats, but fast-track authority was subsequently given by the Senate to President Obama near the end of the month.

Overall, we can see that the series increases when contentious changes in trade regulation (through international treaties) are discussed by policymakers, as well as in months when trade policy is a subject of pre-election debated. Two clear examples are: (i) the period leading to the 1992 Presidential election between George Bush and Bill Clinton, and (ii) the Republican primary of 1996, with Pat Buchanan's anti free-trade rhetoric 'Putting Americans First.'

\subsection{Trade PCI vs alternative measures of political uncertainty}

The methodology used to calculate TCPI is similar to that used by Azzimonti (2018) to compute the Partisan Conflict Index and that of Backer, Bloom, and Davis (2016) to compute Economic Policy Uncertainty (EPU). It is illustrative to compare the behavior of TCPI to these alternative measures of political uncertainty.

The search terms in the first two categories (Political Disagreement and Government) are identical to those used to compute the benchmark PCI. Because the newspapers included in the database and the filters applied are exactly the same, Trade PCI is, strictly speaking, a sub-component of the benchmark PCI series. Figure 5 depicts the monthly TPCI together with the benchmark PCI. The first thing to note is that TPCI is much more volatile than PCI. This is the case because disagreement over trade policy is discussed less often than other fiscal policies and regulations such as taxes, debt, and welfare programs. Moreover,

\footnotetext{
${ }^{10}$ Also, during that month, 'President Reagan outlined a trade policy consisting of three parts: tough action against other nations' unfair trade practices, negotiations to liberalize world trade, and international economic policy reforms' (Office of the United States Trade Representative, 1986). His position generated much debate among policymakers.
} 


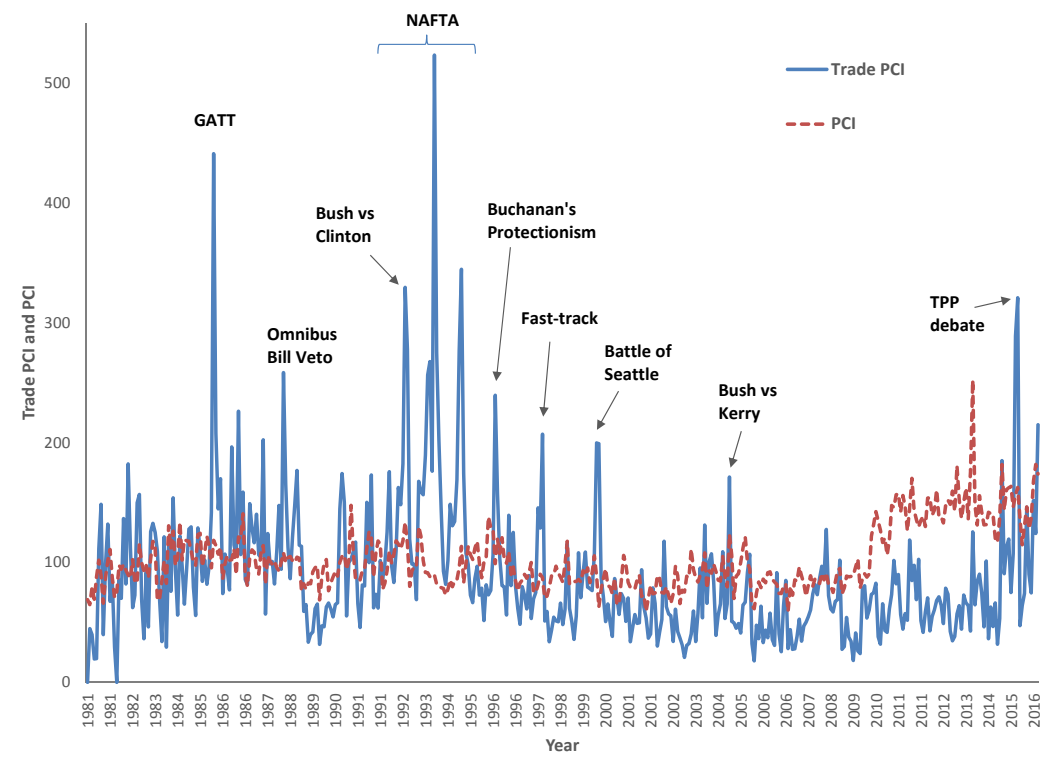

Figure 5: Trade PCI vs PCI.

the discussions are typically centered around very specific events, NAFTA being the most noticeable one. A second difference is that while the benchmark PCI exhibits a structural break after the Great Recession, the TPCI fluctuates around a constant mean during the whole sample. The correlation between the monthly indexes over the whole period is just 0.20 .

Figure 6 depicts TPCI and EPU over time. Note that since EPU is computed only since 1985, the plot starts on that year. As with PCI, we can observe that TPCI is more volatile than EPU for most of the sample, with the exception of the period 2008-2014 when it is actually smaller than EPU. The two series are basically uncorrelated over time, with a correlation coefficient of -0.03 .

\subsection{Trade PCI and the economy}

Figure 7 shows the TPCI (left axis, solid line) together with the Output Gap (right axis, broken line) at the quarterly frequency between 1985:Q1 and 2016:Q1. The output gap is computed as the difference between Real GDP and Potential Real GDP in billions of dollars. The variables, which are only available at a quarterly frequency, are obtained from FRED (see Appendix 6.4 for details). There is no clear pattern in the evolution of the two variables, which exhibit a slightly positive correlation of just 0.17 . For comparison, the correlation between the benchmark PCI and the output gap is -0.4, whereas that between EPU and the 


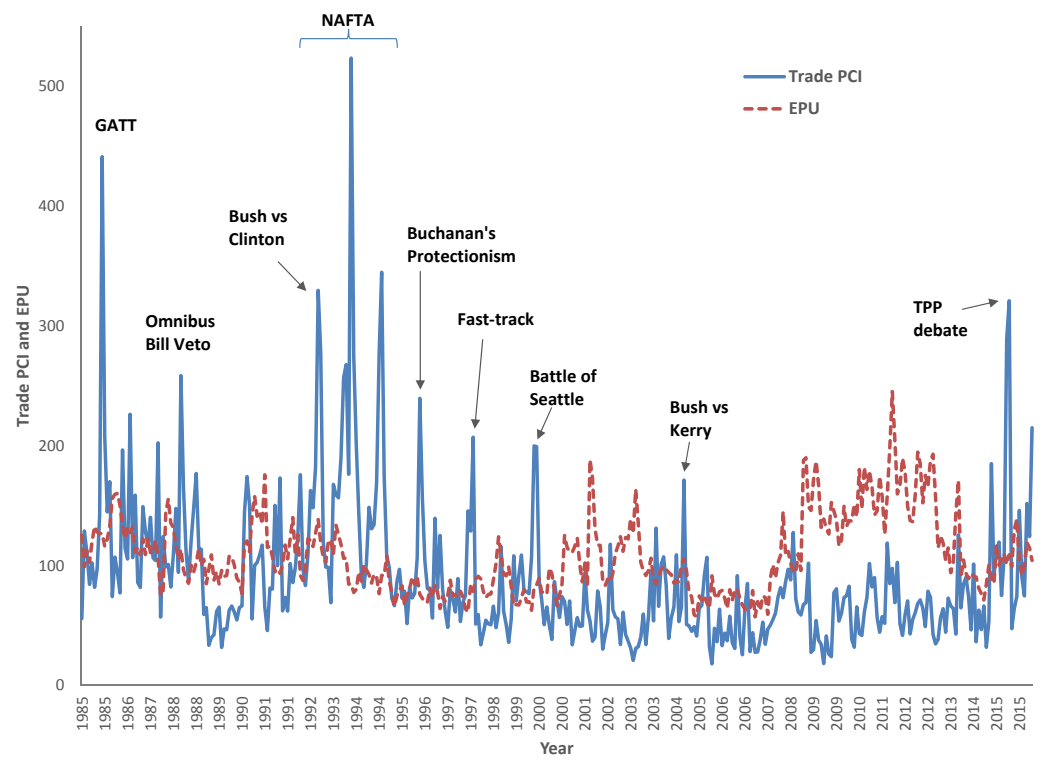

Figure 6: Trade PCI vs EPU.

output gap is -0.69 , both clearly counter-cyclical. ${ }^{11}$

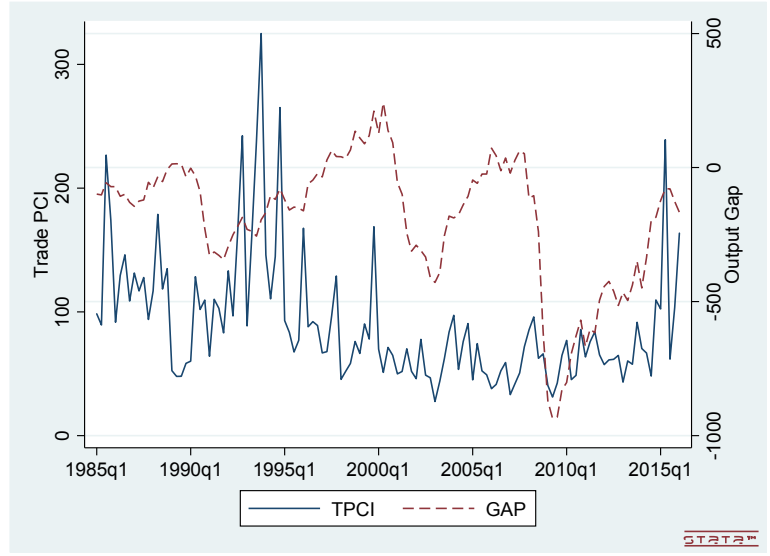

Figure 7: Trade PCI vs Output Gap.

There is, however, some seasonality in TPCI which is tyically higher in the 4th quarter of every year. Whereas TCPI is on average 85 in the first three quarters, it reaches an average of 107 in Q4. A simple t-test indicates that the null hypothesis of equal TPCI in the fourth quarter to the one on the first three quarters is rejected. When a similar test is computed for

\footnotetext{
${ }^{11}$ Note that a negative output gap indicates that the economy is producing below capacity. Hence, a negative correlation between the variable of interest and the output gap indicates counter-cyclicality, as these variable rises during recessions.
} 
the benchmark PCI and EPU, the null cannot be rejected (that is, there is no statistically significant difference between the first three quarters and the last one). I considered the possibility that such difference may be driven by the fact that elections are typically held in the last quarter, and hence more conflict surrounded trade policy is observed at that time. However, there is no difference (statistically speaking) between Presidential (and midterm) election quarters and non-elections quarters.

\section{$3 \quad$ Aggregate FDI inflows}

This section describes the benchmark model used to estimate the effects of domestic political discord on FDI inflows to the US using aggregate data. I consider investment flows to the US by foreign investors from the rest of the world in the form of foreign direct investment. The analysis comprises the period 1985:Q1 to 2016:Q1, with data measured at the quarterly level. ${ }^{12}$

\section{Foreign Direct Investment}

The FDI dataset is obtained from the Flow of Funds, Balance Sheets, and Integrated Macroeconomic Accounts compiled by the Board of Governors of the Federal Reserve System (US). The information is contained in Table S.9.q of the 'Integrated Macroeconomic Accounts for the United States,' in statistical releases 'Z.1 Financial Accounts of the United States' provided by the BEA. This dataset is based on internationally accepted set of guidelines for the compilation of national accounts, and tries to harmonize the BEA National Income and Product Accounts (NIPAs) and the Federal Reserve Board Flow of Funds Accounts (FFAs). Foreign direct investment in the U.S. refers to ownership by a foreign country's residents of at least ten percent of a business in the US. The direct investor is known as a parent, and the parent's foreign business is known as a US-affiliate. The flow of foreign direct investment in the United States will be referred to as FDIUS in the remainder if the analysis. These flows capture the funds that foreign parents provide to their US-affiliates including equity investment, intra-company loans, and reinvested earnings. FDI positions, which are reported annually, measure the stock of foreign direct investment in the US at the end of a given year. It corresponds to cumulative FDIUS, and will be referred to as Positions in the analysis. See Appendix 6.4 for a direct link to the historical series of these variables.

Table 1 summarizes FDI flows and levels in the US by the rest of the world (in US millions). The quarterly average FDI inflow to the US is $\$ 151,237$ million dollars, constituting $1.3 \%$ of quarterly GDP and about $11 \%$ of the stock of FDI in the country (about $\$ 1,543,478$ million dollars).

The evolution of FDI inflows as a percentage of FDI positions in the US can be seen in Figure 8.

\footnotetext{
${ }^{12}$ I choose this start date because some control variables only have availability starting in 1985.
} 
Table 1: Foreign Direct Investment in the US

\begin{tabular}{lccccc}
\hline Variable & Label & Average & Std. Dev. & Min & Max \\
\hline FDI flow & FDIUS & 151,237 & 152,380 & $-289,416$ & 993,936 \\
FDI stock (Position) & Position & $1,543,478$ & $1,100,749$ & 228,408 & $4,071,921$ \\
FDI flow/GDP & $F D I_{t}^{G}$ & $1.3 \%$ & $1.0 \%$ & $-1.7 \%$ & $5.9 \%$ \\
Position/GDP & Position $_{t}^{G}$ & $12.7 \%$ & $4.9 \%$ & $5.4 \%$ & $22.2 \%$ \\
FDI flow/Position[t-1] & $F D I_{t}^{P}$ & $11.1 \%$ & $8.6 \%$ & $8.7 \%$ & $59.4 \%$ \\
\hline
\end{tabular}

Notes: FDIUS corresponds to foreign direct investment flows in the United States by the rest of the world and Position refers to the stock of foreign direct investment, both reported quarterly and in million of dollars. $G D P$ is gross domestic product. Coverage 1985:Q1 to 2016:Q1. See Appendix 6.4 for variables and sources.

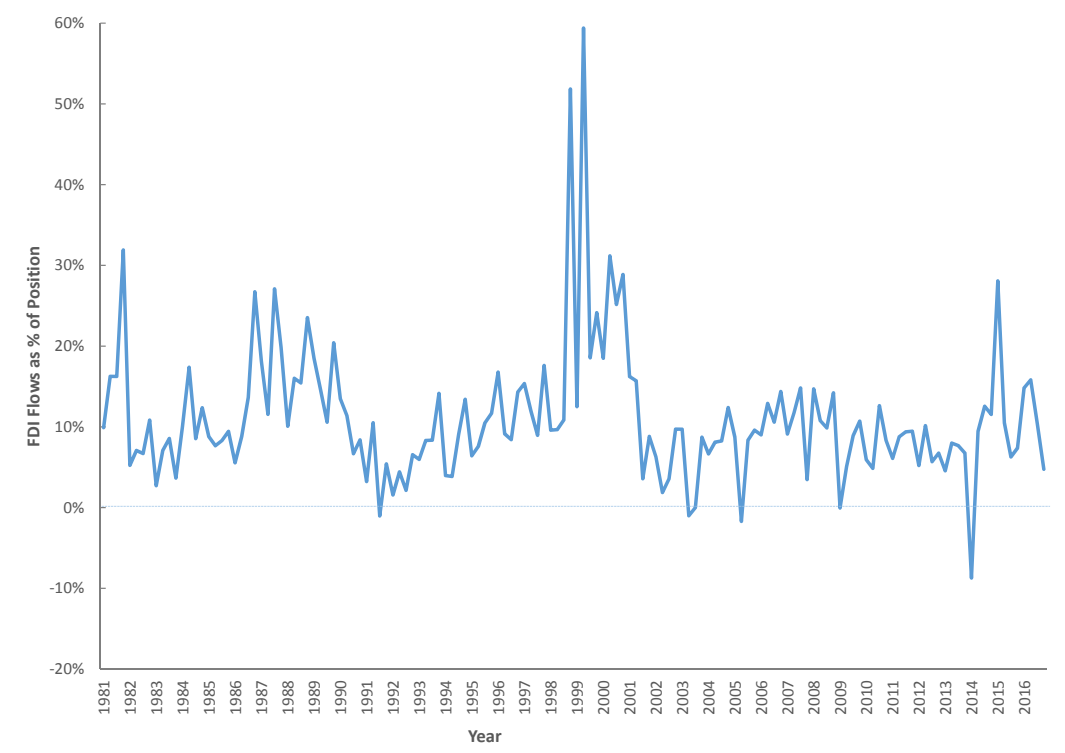

Figure 8: Foreign Direct Investment Flows as \% of FDI stock, 1981:Q1 to 2016:Q1.

Source: FRED database (Federal Reserve Bank of St. Louis). For more details see Appendix 6.4.

\subsection{Model Specification}

Following Baker, Foley and Wurgler (2009), the dependent variable is analyzed is $F D I_{t}^{P}$, which corresponds to FDIUS (in a given quarter) scaled by the cumulative FDI position in the US at the end of quarter $t-1$,

$$
F D I_{t}^{P}=\frac{F D I U S_{t}}{\text { Position }_{t-1}}
$$

The benchmark specification is as follows

$$
F D I_{t}^{P}=\gamma+\alpha_{1} T P C I_{t}+\alpha_{2} T P C I_{t-1}+\mathbf{Z}_{t}^{\prime} \theta+\mathbf{Q T R}_{t}^{\prime} \mu+\epsilon_{t},
$$


where TPCI stands for the Trade Partisan Conflict Index, where we allow for both lagged and contemporaneous effects. At a quarterly frequency, it is possible that news about partisan conflict over trade affect foreign investors with some delay (we would not expect this to happen, for example, at an yearly frequency). The set of macroeconomic indicators is composed of the following: $\mathbf{Z}_{t}=\left\{G D P g r_{t}, G A P_{t}, \Delta F X_{t}, \pi_{t}, F F_{t}, \Delta\right.$ Trade $\left._{t}, E_{t}\right\}$. ALFRED, the electronic database maintained by Federal Reserve Bank of St. Louis, is the primary source of these variables. Summary statistics for these indicators are included in the top panel of Table 2.

GDP growth, GDPgr, controls for the state of the domestic economy; we expect FDI inflows to be higher during booms than in recessions. I also include the output gap $G A P_{t}$, an alternative control for the business cycle. $G A P$ is computed as the difference between real and potential GDP in a given quarter. Changes in the exchange rate, $\Delta F X$, affect the relative wealth levels of foreign and domestic investors, leading to changes in foreign investors' relative purchasing power (see Klein and Rosengren, 1994). Good monetary policy that leads to low inflation is likely to reduce the risk premium for foreign investment, and hence boost FDI inflows. I also include the Federal Funds Rate, $F F_{t}$ as an alternative measure of monetary policy. Both inflation and the FF rate are introduced to control for other forms of policy distortion such as monetary imbalances (see Busse and Hefeker, 2007).

Trade openness, measured as $\frac{X+I}{G D P}$, can affect FDI inflows in two ways. First, trade openness facilitates the import of foreign inputs needed for production in the US and makes it easier to export the final product to other countries (increasing potential demand and hence the returns to FDI). There are also externalities, as suggested by Lipsey and Weiss (1984), by which a firm may expect its production presence in the US to generate demand for other products of this firm (even if they were to be produced aborad). These factors suggest that trade openness promotes FDI. Second, as noted by Markusen (1995) and others, trade barriers may cause a substitution away from exports towards FDI. The intuition is that the higher the tariff, for example, the more likely a foreign firm is to supply the US market from US-affiliates rather than through exports. These factors suggest that trade openness discourages FDI.

Similarly to TPCI, Presidential elections may introduce policy uncertainty, and may discourage FDI inflows (see Julio and Yook, 2016). Because the timing of elections is known ex-ante, I introduce it as an additional control $E_{t}$ which equals 1 in the quarter in which a Presidential election is held and zero otherwise. Summary statistics for TPCI and E can be found in the bottom top panel of Table 2. Finally, in order to control for potential seasonality in FDI, a set of quarter-dummies are introduced. The vector $\mathbf{Q T R}_{t}$ encompasses three dichotomic variables $\mathbf{Q} \mathbf{T R}_{t}=\left\{Q_{2, t}, Q_{3, t}, Q_{4, t}\right\}$, with $Q_{2, t}=1$ in the second quarter and zero otherwise $\left(Q_{3, t}\right.$ and $Q_{4, t}$ are analogously defined).

\subsection{Empirical Results}

Table 3 reports the results. All variables have been normalized by their sample standard deviation in order to simplify the interpretation of coefficients and ease comparison across covariates. Each estimated coefficient represents how $F D I_{t}^{P}$ (normalized by its standard deviation) responds to a one-standard-deviation increase in the respective independent variable. 
Table 2: Summary statistics for control variables

\begin{tabular}{lccccc}
\hline Variable & Label & Average & Std. Dev. & Min & Max \\
\hline & & & & & \\
Macroeconomic indicators & & & & & \\
& & & & & \\
GDP Growth \% & GPgr & 2.64 & 2.4 & -8.2 & 7.8 \\
Output Gap & $G A P$ & -188 & 241 & -935 & 241 \\
Inflation & $\pi$ & 0.66 & 0.51 & -2.3 & 1.7 \\
Exchange Rate (change) & $\Delta F X$ & -0.022 & 0.199 & -0.559 & 0.521 \\
Federal Funds Rate & $F F$ & 3.85 & 2.83 & 0.07 & 9.73 \\
Trade Openness (change) & $\Delta$ Trade & 0.016 & 0.153 & -0.856 & 0.345 \\
& & & & & \\
Political indicators & & & & & \\
& & & & & \\
Trade Partisan Conflict Index & $T P C I$ & 90.1 & 51.1 & 27.6 & 324.9 \\
Elections & $E$ & 0.056 & 0.23 & 0 & 1 \\
Partisan Conflict Index & $P C I$ & 103.2 & 24.8 & 67.9 & 177.2 \\
Economic Policy Uncertainty & $E P U$ & 107.7 & 29.8 & 63.1 & 215.9 \\
\hline
\end{tabular}

Notes: Coverage 1985:Q1 to 2016:Q1. See Appendix 6.4 for a description of variables and sources.

The first row denotes the estimated coefficient, while robust standard errors (corrected for autocorrelation by using an $\operatorname{AR}(2)$ specification) are reported in parenthesis.

Specification (1) corresponds to the regression eq. (1), where the dependent variable is the ratio of FDI to lagged positions in the US. While contemporaneous Trade PCI is statistically insignificant (that is, we cannot reject the null hypothesis that its estimated coefficient is zero), lagged Trade PCI has a negative and significant coefficient. A one standard-deviation increase in political discord regarding trade policy results in a reduction of 0.127 standard deviations in FDI inflows (as a percentage of the total position). To put this number in perspective, note that a one-standard deviation increase in Trade PCI results in a decline of $F D I_{t}^{P}$ of $9.8 \%$ from its mean value in a given quarter. This number is calculated as $0.098=-0.127 \times 0.086 / 0.111$, where -0.127 is the estimated coefficient, 0.086 is the standard deviation of $F D I_{t}^{P}$, and 0.111 corresponds to the average value of $F D I_{t}^{P}$ over the sample. We can also see from the regression results that a positive output gap (e.g. the economy is above trend) induces FDI inflows to the US. Other control variables are not statistically significant, with the exception of $Q_{4, t}$ (omitted from the table) which has a positive estimated coefficient.

Uncertainty over Fiscal and Monetary Policy: Trade PCI controls for a very specific source of political uncertainty, namely disagreement among policymakers about trade policy. It is possible that uncertainty over fiscal policy more generally (such as corporate taxes and production subsidies), as well as other government regulation (e.g. on financial markets) also affect FDI inflows to the US. By not including a control for these additional sources of uncertainty the coefficient on TPCI (and its first lag) may be biased, especially since trade 
Table 3: Regression Results, Aggregate Data

\begin{tabular}{|c|c|c|c|c|c|}
\hline Dependent Var & $(1)$ & $\begin{array}{l}\text { Flow } \\
(2)\end{array}$ & $\begin{array}{c}\text { Position } \\
\quad(3)\end{array}$ & $(4)$ & $\begin{array}{c}\text { Busse-Hefeker } \\
(5)\end{array}$ \\
\hline$T P C I_{t}$ & $\begin{array}{c}0.050 \\
(0.069)\end{array}$ & $\begin{array}{c}0.045 \\
(0.072)\end{array}$ & $\begin{array}{c}0.054 \\
(0.069)\end{array}$ & $\begin{array}{c}0.076 \\
(0.067)\end{array}$ & $\begin{array}{c}0.079 \\
(0.067)\end{array}$ \\
\hline$T P C I_{t-1}$ & $\begin{array}{c}-0.127^{* *} \\
(0.052)\end{array}$ & $\begin{array}{c}-0.126^{* *} \\
(0.054)\end{array}$ & $\begin{array}{c}-0.135^{* *} \\
(0.055)\end{array}$ & $\begin{array}{c}-0.141^{* * *} \\
(0.053)\end{array}$ & $\begin{array}{c}-0.144^{* * * *} \\
(0.053)\end{array}$ \\
\hline$G A P_{t}$ & $\begin{array}{l}0.317^{*} \\
(0.184)\end{array}$ & $\begin{array}{l}0.319^{*} \\
(0.185)\end{array}$ & $\begin{array}{l}0.376^{*} \\
(0.222)\end{array}$ & $\begin{array}{l}0.353^{*} \\
(0.206)\end{array}$ & $\begin{array}{l}0.357^{*} \\
(0.205)\end{array}$ \\
\hline$\Delta$ Trade $_{t}$ & $\begin{array}{c}0.638 \\
(0.527)\end{array}$ & $\begin{array}{l}0.637 \\
(0.531)\end{array}$ & $\begin{array}{c}0.820 \\
(0.511)\end{array}$ & $\begin{array}{l}1.021^{*} \\
(0.620)\end{array}$ & $\begin{array}{l}1.029 \\
(0.628)\end{array}$ \\
\hline$\Delta F X_{t}$ & $\begin{array}{c}0.768 \\
(0.520)\end{array}$ & $\begin{array}{c}0.766 \\
(0.522)\end{array}$ & $\begin{array}{l}0.881^{*} \\
(0.458)\end{array}$ & $\begin{array}{c}1.046^{* * *} \\
(0.398)\end{array}$ & $\begin{array}{c}1.062^{* * *} \\
(0.397)\end{array}$ \\
\hline$G D P g r_{t}$ & $\begin{array}{c}0.060 \\
(0.122)\end{array}$ & $\begin{array}{c}0.060 \\
(0.122)\end{array}$ & $\begin{array}{l}0.073 \\
(0.129)\end{array}$ & $\begin{array}{c}0.099 \\
(0.161)\end{array}$ & $\begin{array}{c}0.103 \\
(0.158)\end{array}$ \\
\hline$\pi_{t}$ & $\begin{array}{l}-0.018 \\
(0.085)\end{array}$ & $\begin{array}{l}-0.018 \\
(0.085)\end{array}$ & $\begin{array}{l}-0.027 \\
(0.092)\end{array}$ & $\begin{array}{c}0.014 \\
(0.098)\end{array}$ & $\begin{array}{c}0.013 \\
(0.099)\end{array}$ \\
\hline$F F_{t}$ & $\begin{array}{c}0.128 \\
(0.215)\end{array}$ & $\begin{array}{c}0.140 \\
(0.217)\end{array}$ & $\begin{array}{c}0.130 \\
(0.213)\end{array}$ & $\begin{array}{c}0.077 \\
(0.193)\end{array}$ & $\begin{array}{c}0.084 \\
(0.191)\end{array}$ \\
\hline$P C I_{t}$ & & $\begin{array}{c}0.029 \\
(0.119)\end{array}$ & $\begin{array}{l}-0.003 \\
(0.115)\end{array}$ & $\begin{array}{c}0.028 \\
(0.121)\end{array}$ & $\begin{array}{c}0.029 \\
(0.122)\end{array}$ \\
\hline$E P U_{t}$ & & & $\begin{array}{c}0.111 \\
(0.145)\end{array}$ & $\begin{array}{c}0.224 \\
(0.165)\end{array}$ & $\begin{array}{c}0.228 \\
(0.163)\end{array}$ \\
\hline Leading $_{t}$ & & & & $\begin{array}{l}-0.170 \\
(0.180)\end{array}$ & $\begin{array}{l}-0.172 \\
(0.180)\end{array}$ \\
\hline Sentiment $_{t}$ & & & & $\begin{array}{l}0.283^{*} \\
(0.155)\end{array}$ & $\begin{array}{l}0.283^{*} \\
(0.156)\end{array}$ \\
\hline $\mathbf{Q T R}_{t}+E_{t}$ & Yes & Yes & Yes & Yes & Yes \\
\hline Observations & 125 & 125 & 125 & 125 & 125 \\
\hline
\end{tabular}

policy is often discussed together with other budgetary items. To control for these, I first augment the benchmark specification by introducing the benchmark PCI measure computed by Azzimonti (2018). The results are presented in column (2). We can see that the coefficient on lagged TPCI is basically unchanged. Including, in addition, a lag on benchmark PCI does not alter this (results omitted but available upon request).

Under column (3), I also include the Economic Policy Uncertainty Index (EPU) developed by Baker or Bloom, and Davis (2016) as an additional control. The value of this coefficient is statistically insignificant as seen by the large standard error of its coefficient. Interestingly, the magnitude and significance of TPCI remains unchanged. Introducing a first lag on EPU does not change the results (omitted from the table). That the coefficient on EPU has a large 
p-value may be due to the fact that this variable is highly (negatively) correlated with both, the federal funds rate and the output gap. The correlation between (lagged) EPU and $F F$ is -0.41 , whereas its correlation with $G A P$ is -0.73 . If both $F F$ and $G A P$ were excluded from the regression, lagged EPU would have a statistically significant coefficient. ${ }^{13}$

The role of expectations: Previous literature discussing the effects of policy uncertainty (Gulen and Ion, 2015, Baker, Bloom, and Davis, 2016) and partisan conflict (Azzimonti, 2018) on aggregate investment raised two potential issues with identification. First, there may be a problem of reverse causality. It is possible that policymakers' disagreement over the course of economic policy heightens when the economy is in a recession, which is also a period in which investment tends to be low. Second, there may be omitted variables bias by failing to control for other variables, such as expectations over business cycle conditions, affecting policy uncertainty measures and investment. The first issue is less significant in the current study. The reason being that it is unlikely that discussions over trade policy are driven by FDI inflows or outflows.

Omitted variable bias caused by failing to control for investment opportunities is potentially a more serious concern. Following Gulen and Ion (2015), I consider two alternative measures of expectations: the Michigan consumer confidence index and the Federal Reserve Bank of Philadelphia leading index. The consumer confidence index, denoted by Sentiment ${ }_{t}$, is constructed by the University of Michigan and proxies consumer expectations about the

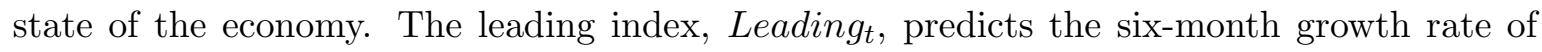
the coincident index, state-level housing permits (1 to 4 units), unemployment insurance claims, and other leading indicators. It proxies expectations about GDP growth. These two variables, normalized by their standard deviations, are added as additional regressors. The estimated coefficients are shown in column (4) of Table 3. While we cannot reject the hypothesis that Leading has no effect on FDI inflows, Sentiment seems to have a positive impact. A one-standard deviation in Sentiment is associated with a 0.283 standard deviation increases in $F D I^{p}$. We can see that increases in $\Delta F X_{t}$ are also positively associated with FDI inflows. Finally, the effect of Trade PCI is slightly more negative in this case: a one-standard deviation increase in lagged TPCI results in a 0.141 standard-deviation decline in FDI flows.

Busse and Hefeker: For robustness, I also consider a log-transformation of the dependent typically used in the empirical FDI literature developed by Busse and Hefeker (2007)

$$
\ln F D I_{i, t}^{P}=\ln \left(F D I_{i, t}^{P}+\sqrt{\left(F D I_{i, t}^{P}\right)^{2}+1}\right) .
$$

\footnotetext{
${ }^{13}$ I find that in such case a one-standard deviation increase in EPU results in a -0.18 standard deviations decline in $F D I^{p}$. The coefficient on $E P U_{t}$ would still be insignificant though. This modification, on the other hand, would not change the magnitude of the estimated coefficient of TPCI.
} 
The last column in Table 3 summarizes the result of a specification analogous to the one presented in column (4), where $\ln F D I_{i, t}^{P}$ is normalized by its standard deviation. The coefficient is less intuitive to interpret in this case, but the main message is that the effect of Trade PCI on log-FDI flows is negative and statistically significant.

\section{FDI flows by country}

Using country-specific data on foreign direct investment, it is possible to further identify the effects of political dysfunction on FDIUS inflows. The main advantage of this approach is that we can better control for omitted variables bias by including country fixed-effects and country-specific control variables, in addition to controlling for macroeconomic conditions in the country of origin which may also affect FDI flows (bilateral exchange rates, bilateral trade, etc). The main disadvantage is that data is available annually for a wide range of countries, and that disaggregated information is not available for all countries.

\subsection{Data on country-specific FDI}

The sample used includes information from 38 countries on foreign direct investment to the US, over the interval 1985-2016. The FDI series are obtained from the Survey of US Direct Investment Abroad, undertaken by the US Bureau of Economic Analysis. ${ }^{14}$ FDI inflows from country $i, F D I U S_{i}$, is reported in millions of US dollars. As in the previous section, direct investment in the U.S. refers to ownership by a foreign country's residents of at least ten percent of a business in the US. The third and fifth columns of Table 4 summarize the average $F D I U S_{i, t}$ per country of origin. The average annual FDI inflows range from a low of $\$ 8$ million from Kuwait to a high of $\$ 24$ billion from the United Kingdom.

\footnotetext{
${ }^{14}$ Foreign Direct Investment in the U.S.: Balance of Payments and Direct Investment Position Data, Financial transactions without current-cost adjustment.
} 
Table 4: FDI inflows per parent country

\begin{tabular}{lcclcc}
\hline Country & $F D I_{i, t}^{P}$ & $F D I U S_{i, t}$ & Country & $F D I_{i, t}^{P}$ & $F D I U S_{i, t}$ \\
\hline Australia & 0.172 & 1,970 & Korea & -0.551 & 1,417 \\
Austria & 0.187 & 290 & Kuwait & 0.125 & 8 \\
Belgium & 0.143 & 2,079 & Luxembourg & 0.331 & 19,194 \\
Bahamas & -1.057 & 14 & Mexico & 0.326 & 920 \\
Brazil & -2.996 & 133 & Malaysia & 0.506 & 29 \\
Canada & 0.134 & 15,093 & Netherlands & 0.121 & 16,242 \\
Chile & -0.011 & 23 & Norway & 0.222 & 1,105 \\
Colombia & -0.705 & 48 & New Zealand & 0.195 & 65 \\
Germany & 0.147 & 12,943 & Panama & 0.088 & 453 \\
Denmark & 0.239 & 716 & Philippines & 0.955 & 41 \\
Finland & 0.222 & 378 & Singapore & 0.318 & 1,267 \\
France & 0.167 & 11,186 & Spain & 0.284 & 2,330 \\
Hong Kong & 0.193 & 544 & South Africa & -0.142 & 90 \\
Hungary & 1.057 & 197 & Sweden & 0.141 & 2,020 \\
Indonesia & 1.868 & 59.875 & Switzerland & 0.158 & 12,599 \\
Ireland & 0.303 & 2,959 & Taiwan & 0.223 & 289 \\
Israel & 0.145 & 535 & United Kingdom & 0.152 & 24,030 \\
Italy & 0.158 & 1,263 & United Arab Emirates & 0.805 & 41 \\
Japan & 0.123 & 15,093 & Venezuela & 1.88 & -52 \\
\hline
\end{tabular}

Notes: Sample period 1985 to 2016. The second and fourth columns show average foreign direct investment (FDI) inflows from country $i$ to the US in a given year as a percentage of lagged positions in that country. The third and fifth columns display FDI inflows in millions of US dollars. See the Appendix 6.5 for variable descriptions and sources.

The second and fourth columns of Table 4 report $F D I_{t}^{P}$, the average FDI inflows from country $i$ in year $t$ as a ratio of the (lagged) stock of FDI from country $i$ in the US. That is,

$$
F D I_{i, t}^{P}=\frac{F D I U S_{i, t}}{\text { Position }_{t-1}^{i \rightarrow U S}}
$$

where following Julio and Yook (2016), the denominator corresponds to cumulative FDI positions in the US from country $i$. This variable measures the total outstanding level of country $i$ 's direct investment in the US at year-end (e.g. the stock of FDI on the country).

Following Busse and Hefeker (2007), I will also consider the following log transformation of FDI flows:

$$
\ln F D I_{i, t}^{P}=\ln \left(F D I_{i, t}^{P}+\sqrt{\left(F D I_{i, t}^{P}\right)^{2}+1}\right)
$$

Because FDI is measured on a net basis, many country-quarter observations have negative values. This transformation allows us to consider a non-linear relationship between FDI and partisan conflict over trade policy, while at the same time preserving observations with negative values. 
Table 5: Summary statistics of quarterly FDI measures

\begin{tabular}{lcccccc}
\hline Variable & Label & Obs & Average & Std. Dev. & Min & Max \\
\hline Flow (\$ millions) & $F D I U S_{i, t}$ & 1,190 & 3,842 & 11,700 & $-94,851$ & 182,561 \\
Flow/Position & $F D I_{i, t}^{P}$ & 1,190 & 0.253 & 3.08 & -30.15 & 66.75 \\
Busse-Hefeker & $\ln F D I_{i, t}^{P}$ & 1,190 & 0.148 & 0.60 & -4.10 & 4.89 \\
\hline &
\end{tabular}

Summary statistics, averaged over our sample of 38 countries, are presented in Table 5 . Average FDI inflows to the US per parent country are $\$ 3,842$ million dollars each year, or $25.3 \%$ of the total position already in the country.

\subsection{Country Characteristics}

In order to estimate the effects of partisan conflict about trade policy on FDI inflows to the US, it is important to control not only for the state of the domestic economy, but also for characteristics of the parent country. In particular, I will consider: (i) changes in parent country trade openness, where openness is measured as $\frac{X_{i}+I_{i}}{G D P_{i}}$ with $i$ denoting the parent-country; (ii) changes in bilateral trade, where bilateral trade is measured as $\frac{X_{i}^{U S}+I_{i}^{U S}}{G D P_{i}}$, with $M_{i}^{U S}$ and $X_{i}^{U S}$ denote US imports and exports, respectively, from/to country $i$, (iii) percentage changes in the bilateral exchange rate, measured as National Currency/US dollar; (iii) country $i$ 's real GDP growth, and (iv) parent-country's inflation rate, measured as the percentage change in country $i$ 's consumer prices. More detailed description of these variables and their sources can be found on Appendix 6.5. Table 6 summarizes the characteristics of the 38 countries in our sample.

Table 6: Parent country characteristics

\begin{tabular}{lcccc}
\hline & Label & Obs & Average & Std. Dev. \\
\hline Variable & $G D P g r_{i, t}$ & 1,190 & 3.2 & 4.5 \\
Trade Openth, \% & $\Delta F X_{i, t}$ & 1,148 & 77.5 & 74.0 \\
\% Change in Trade Openness & $\Delta$ Trade $_{i, t}$ & 1,148 & 0.8 & 19 \\
\% Change Bilateral Trade & $\Delta$ Bilateral $_{i, t}$ & 1,148 & -0.4 & 15.12 \\
Change in Bilateral Exchange Rate & $\Delta F X_{i, t}$ & 1,148 & 14.02 & 194.0 \\
Inflation Rate, \% & $\pi_{i, t}$ & 1,190 & 14.8 & 130.9 \\
\hline
\end{tabular}

Notes: Sample period 1985 to 2016, for 38 countries. See the Appendix 6.5 for variable descriptions and sources.

Trade openness, measured as the ratio between the sum of exports and imports and GDP, averages $77 \%$ of GDP across countries. This is in line with Julio and Yook (2016)'s value of around $80 \%$. Changes in this variable average $0.8 \%$. Bilateral trade represents around $10 \%$ of the country's output in the sample, and the average change is $-0.4 \%$. The mean growth in 
real GDP has been $3.2 \%$, with a standard deviation of around $4.5 \%$. The average inflation rate is $14.8 \%$, mostly driven by the observations in Latin America. If these are excluded, average inflation is $4.4 \%$ instead.

\subsection{Model specification and empirical results}

Exploiting the panel structure of the data, I will compute a fixed-effects regression of the form

$$
F D I_{i, t}^{P}=\gamma_{i}+\alpha T P C I_{t}+\mathbf{X}_{i, t}^{\prime} \beta+\mathbf{Z}_{t}^{\prime} \theta+\epsilon_{i, t},
$$

where $F D I_{i, t}^{P}$ is FDI flows from country $i$ as a ratio of lagged positions in the US. As before, $T P C I_{t}$ stands for the Trade Partisan Conflict Index in the US. The vector $\mathbf{X}$ denotes the set of country-specific control variables, $\mathbf{X}_{i, t}=\left\{G D P g r_{i, t}, \Delta F X_{i, t}, \Delta\right.$ Trade $_{i, t}, \Delta$ Bilateral $\left._{i, t}, \pi_{i, t}\right\}$. Economic conditions of the parent country are captured by the growth rate of its GDP, $G D P g r_{i, t}$, changes in the relative wealth of foreigners by $\Delta F X_{i, t}$, changes in the degree of trade openness by $\Delta$ Trade $_{i, t}$, changes in the bilateral trade between country $i$ and the US by $\Delta$ Bilateral $_{i, t}$, and the parent country's inflation rate by $\pi_{i, t}$ (measured as the change in average consumer prices in country $i$ ). I also control for time-invariant country characteristics that may affect FDI flows by including country fixed-effects, denoted by $\gamma_{i}$. Examples are geographic and language proximity and legal origin (see Daude and Fratzscher, 2008) or the degree of financial liberalization, which is mostly invariant over this time period.

I also incorporate a set of variables that control for the political environment and business cycle conditions in the US, $\mathbf{Z}_{t}=\left\{G D P g r_{t}, G A P_{t}, \pi_{t}, F F_{t}, E_{t}\right\}$. These correspond to the set of controls in the benchmark specification analyzed in Section 3.1 for aggregate data. They are: the growth rate of real GDP, GDPgr ${ }_{t}$, the output gap, GAP, the inflation rate in the US, $\pi_{t}$ (measured as the change in average consumer prices in the US), the Federal Funds Rate, $F F_{t}$, and the indicator variable $E_{t}$ which equals 1 in years in which a Presidential election is held and zero otherwise. These time-varying variables are included to control for other trends that may be correlated with the Trade PCI, but affect FDI inflows independently, and hence reduce a potential omitted variables problem. Sources and details for the variables included in $\mathbf{Z}_{t}$ can be found on Appendix 6.4.

Table 7 summarizes the main results from the regression. As in the previous section, all variables have been normalized by their sample standard deviation. Column (1) reports the regression coefficients corresponding to the specification represented in eq. (2). Standard errors are clustered by parent country, and corrected for heteroskedasticiy and autocorrelation (in parenthesis). The estimated coefficient implies that a one standard-deviation increase in Trade PCI is associated with an average decline of 0.04 standard-deviations in FDI inflows from a given country in a given year. This value implies that a $10 \%$ increase in Trade PCI from its mean (of 91) corresponds to a $11.2 \%$ decline in the FDI ratio from its average value of $0.253 .^{15}$ The regression also shows that an increase in one standard deviation in the growth

\footnotetext{
${ }^{15}$ To compute this number note that the change in $F D I_{i, t}^{P}$ units when Trade PCI rises in one unit is $-0.003=-0.04 \times 3.08 / 41$, where -0.04 is the estimated coefficient, 3.08 is the standard deviation in $F D I_{i, t}^{P}$, and 41 is the standard deviation in Trade PCI. Hence, a 10\% increase in Trade-PCI from its mean (e.g. 9.1 units) results in a $0.0279=-0.003 \times 9.1$ decline in $F D I_{i, t}^{P}$. This, in turn, corresponds to an $11.2 \%$ decline from its mean, e.g. $-0.112=-0.0279 / 0.253$, where 0.253 is the average value of $F D I_{t}^{P}$ in the sample.
} 
Table 7: Regression Results in Panel Data

\begin{tabular}{|c|c|c|c|c|c|}
\hline \multirow[t]{2}{*}{ Dependent Var } & \multicolumn{4}{|c|}{ Flow/Position } & \multirow{2}{*}{$\begin{array}{c}\text { Busse-Hefekeı } \\
(5)\end{array}$} \\
\hline & (1) & $(2)$ & (3) & (4) & \\
\hline \multirow[t]{2}{*}{$T P C I$} & $-0.041^{* *}$ & $-0.041^{* *}$ & $-0.040 * *$ & $-0.053^{* *}$ & $-0.086^{* * *}$ \\
\hline & $(0.016)$ & $(0.015)$ & $(0.015)$ & $(0.020)$ & $(0.031)$ \\
\hline \multirow[t]{2}{*}{$G D P g r_{i, t}$} & $0.082^{*}$ & $0.082^{*}$ & $0.080^{*}$ & $0.080^{*}$ & $0.126^{* *}$ \\
\hline & $(0.042)$ & $(0.042)$ & $(0.041)$ & $(0.042)$ & $(0.056)$ \\
\hline \multirow[t]{2}{*}{$\Delta F X_{i, t}$} & $1.182^{* * *}$ & $1.182^{* * *}$ & $1.192^{* * *}$ & $1.193^{* * *}$ & $0.360^{* * *}$ \\
\hline & $(0.061)$ & $(0.057)$ & $(0.059)$ & $(0.060)$ & $(0.070)$ \\
\hline \multirow[t]{2}{*}{$\pi_{i, t}$} & $0.012^{*}$ & $0.012^{*}$ & $0.012^{* *}$ & $0.012^{* *}$ & $0.013^{* *}$ \\
\hline & $(0.006)$ & $(0.006)$ & $(0.006)$ & $(0.006)$ & $(0.006)$ \\
\hline \multirow[t]{2}{*}{$\Delta$ Bilateral $_{i, t}$} & $-0.419^{* *}$ & $-0.419^{* *}$ & $-0.426^{* *}$ & $-0.417^{* *}$ & -0.339 \\
\hline & $(0.195)$ & $(0.193)$ & $(0.199)$ & $(0.198)$ & $(0.252)$ \\
\hline \multirow[t]{2}{*}{$\Delta$ Trade $_{i, t}$} & -0.097 & -0.097 & -0.086 & -0.100 & -0.119 \\
\hline & $(0.077)$ & $(0.076)$ & $(0.070)$ & $(0.091)$ & $(0.139)$ \\
\hline \multirow[t]{2}{*}{$G D P g r_{t}$} & $0.060^{*}$ & 0.060 & 0.060 & $0.103^{* *}$ & $0.117^{* *}$ \\
\hline & $(0.034)$ & $(0.036)$ & $(0.036)$ & $(0.042)$ & $(0.048)$ \\
\hline \multirow[t]{2}{*}{$G A P_{t}$} & -0.007 & -0.007 & -0.087 & -0.026 & 0.055 \\
\hline & $(0.037)$ & $(0.034)$ & $(0.061)$ & $(0.063)$ & $(0.063)$ \\
\hline \multirow[t]{2}{*}{$\pi_{t}$} & -0.027 & -0.027 & -0.019 & $-0.066^{*}$ & -0.080 \\
\hline & $(0.029)$ & $(0.029)$ & $(0.028)$ & $(0.034)$ & $(0.053)$ \\
\hline \multirow[t]{2}{*}{$F F_{t}$} & -0.013 & -0.013 & 0.008 & 0.040 & 0.066 \\
\hline & $(0.035)$ & $(0.035)$ & $(0.037)$ & $(0.039)$ & $(0.065)$ \\
\hline \multirow[t]{2}{*}{$P C I_{t}$} & & 0.001 & 0.025 & 0.021 & -0.004 \\
\hline & & $(0.034)$ & $(0.042)$ & $(0.042)$ & $(0.037)$ \\
\hline \multirow[t]{2}{*}{$E P U_{t}$} & & & $-0.092^{*}$ & $-0.098^{* *}$ & -0.043 \\
\hline & & & $(0.046)$ & $(0.047)$ & $(0.056)$ \\
\hline \multirow[t]{2}{*}{ Sentiment $_{t}$} & & & & $-0.116^{*}$ & $-0.170^{* *}$ \\
\hline & & & & $(0.068)$ & $(0.079)$ \\
\hline \multirow[t]{2}{*}{ Leading $_{t}$} & & & & -0.030 & -0.038 \\
\hline & & & & $(0.042)$ & $(0.051)$ \\
\hline$E_{t}$ & Yes & Yes & Yes & Yes & Yes \\
\hline Observations & 1,148 & 1,148 & 1,148 & 1,148 & 1,148 \\
\hline R-squared & 0.038 & 0.038 & 0.040 & 0.042 & 0.029 \\
\hline Number of countries & 38 & 38 & 38 & 38 & 38 \\
\hline
\end{tabular}

Notes: Sample period 1985to 2016, for 38 countries. Robust standard errors, clustered by country, and corrected for autocorrelation are shown in parentheses. Significance denoted as: $* * * \mathrm{p}<0.01, * * \mathrm{p}<0.05, * \mathrm{p}<0.1$

rate of the home country rises FDI ratios by 0.08 standard deviations. Increases in the speed of depreciation of country $i$ 's currency relative to the dollar (e.g. rises in $\Delta F X_{i, t}$, measured as domestic currency per US dollar) increase FDI inflows to the US (relative to the country's position in the US). Parent-country inflation has a similar effect, as seen by the positive sign of the coefficient on $\pi_{i, t}$. Increases in the rate of bilateral trade of country $i$ are negatively related to FDI inflows to the US, $F D I_{t}^{P}$. However, changes in the overall degree of trade 
openness do not, on average, affect FDI inflows (as seen by the large standard error of its estimated coefficient). The only macroeconomic indicator of the domestic country which has a statistically significant effect is the growth rate of GDP. The positive coefficient indicates that better economic conditions in the US attract FDI inflows into the country. Other control variables are not statistically different from zero, as seen by their large standard errors (in parenthesis).

Uncertainty over Fiscal and Monetary Policy: In column (2) I control for the benchmark $P C I$, whereas in column (3) I add EPU as an additional regressor. While the effect of $P C I$ is null (statistically) once other variables are considered, I find that a onestandard-deviation increase in EPU reduces FDI ratios by 0.09 standard deviations. This value is statistically significant at the $10 \%$ level (e.g. its p-value is smaller than 0.1 ). The effect is larger in magnitude to that of Trade PCI, indicating that uncertainty over fiscal and monetary policy is an important deterrent for foreign investors once bilateral FDI flows are considered. Interestingly, the magnitude and significance of Trade EPU remains unchanged.

The role of expectations: Column (4) incorporates expected GDP growth, Leading

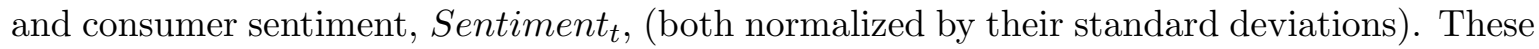
variables are the annual counterparts of the ones used in Section 3. While Leading $_{t}$ does not seem to affect FDI flows, Sentiment $t$ has a negative effect. This is somewhat puzzling given that the result obtained in the aggregate specification had a different sign, and what one would expect from standard macroeconomic intuition. We can see that the coefficient on $F D I_{t}^{P}$ is slightly more negative (i.e. -0.053 ), whereas those corresponding to the other control variables are basically unchanged. The coefficient on US GDP has almost doubled (with a p-value now smaller than 0.05). The sign and magnitude of other regressors is basically unchanged.

Busse and Hefeker: Column (5) estimates the same model as the one in column (4), but considers the transformation of FDI developed by Busse and Hefeker (2007), $\ln F D I_{i, t}^{P}$, also normalized by its standard deviation (see Section 3 for details). The estimated coefficient cannot be directly compared to the one in column (4), but it does indicates that increases in TPCI are associated with significant reductions in (transformed) FDI inflows. Qualitatively, the effect of other independent variables is consistent with the linear specification of column (4).

Robustness: Several robustness exercises were performed in terms of functional form in the regression equation and alternative proxies for some of the control variables. When considering the natural logarithm of Trade PCI and EPU, the sign and significance of the Trade EPU coefficient remains unchanged, but the overall fit of the model worsens. The results are also robust to considering an alternative proxy for aggregate economic conditions 
in the US, namely the growth in the unemployment rate. The results of using this measure instead of GDP growth are summarized in Table 10 of Appendix 6.6. The coefficient on the rate of change of the unemployment rate is negative, indicating that as economic conditions in the US worsen FDI inflows decline. The sign or significance of our variable of interest, $T C P I$, is unchanged.

To summarize, we can see that the main result of this paper, namely that increases in partisan conflict over trade policy are associated with lower FDI inflows to the US, is also robust when a panel of parent-countries is considered. Potential omitted variable bias present in the aggregate specification of Section 3 are addressed by including country fixed effects and other country-specific control variables, as well as time-varying controls for US economic and political conditions.

\subsection{Heterogeneous effects}

In this subsection, I consider the possibility that TPCI has an heterogeneous impact on FDI flows originating from a particular set of countries that may have tighter links with the US or be more affected by specific trade agreements debated by policymakers.

Nafta: The first set of countries considered are Canada and Mexico given their the physical proximity to the US, their trade ties, and the establishment of a free-trade zone through the NAFT A agreement in the early 1990s. To test whether these countries react differently to TPCI then other countries in the sample do, I add the interaction between an indicator variable Nafta - which takes a value of 1 for Canada and Mexico, and zero otherwise - and $T P C I$ in the baseline specification:

$$
Y_{i, t}=\gamma_{i}+\lambda_{t}+\alpha T P C I_{t} \times N a f t a_{i, t}+\mathbf{X}_{i, t}^{\prime} \beta+\epsilon_{i, t},
$$

where $Y_{i, t}$ denotes the benchmark FDI flow measure $F D I_{i, t}^{P}$ or the Busse and Hefeker (2007) transformation, $\ln F D I_{i, t}^{P}$. Notice that since we are no longer interested in estimating the average effect of Trade PCI on foreign direct investment, we can replace the $T P C I_{t}$ term in equation (2) with a time fixed effect, $\lambda_{t}$, in equation (3). This has the additional benefit of controlling for any aggregate macroeconomic conditions in the US that may confound the effect of trade partisan conflict. As a result, the vector $\mathbf{Z}_{t}$ is abstracted from in the regression equation.

The first and second columns of Table 8 show that the estimated value of $\alpha$ is positive and statistically significant. This implies that increases in TPCI have a lower impact on FDI inflows for Canada and Mexico than it does for other countries in the sample. This could happen because these countries are better informed about trade policy and hence do not over-react to news about political uncertainty as much as other countries do. It could also happen because once the Nafta agreement was signed, their foreign direct investment was more protected by other changes in tariffs or import/export quotas debated over the period. It would be interesting to analyze whether there is a change in the sign or magnitude of $\alpha$ pre1994 and post-1994. There are, unfortunately, too few observations in the pre-Nafta period in 
the current panel to study this properly (as most data starts on 1985). Better understanding why Canada and Mexico are actually less susceptible to TPCI is an interesting avenue for future research.

Sub-Regions: Next, I try to disaggregate the information further by analyzing which regions are more sensitive to TPCI over the sample period than Canada and Mexico are. I construct the following indicator variables: (i) Europe takes the value of 1 for Austria, Belgium, Denmark, Finland, France, Germany, Hungary, Ireland, Italy, Luxembourg, Netherlands, Norway, Spain, Sweden, Switzerland, and the United Kingdom and 0 otherwise; (ii) America takes a value of 1 for Bahamas, Brazil, Chile, Colombia, Panama, Venezuela; (iii) Middle equals 1 for Israel, Kuwait, and United Arab Emirates; (iv) EAsia is 1 for Hong Kong, Japan, Korea, and Taiwan; (v) SEAsia is 1 for Malaysia, Philippines, Singapore, and Indonesia; (vi) Other equals 1 for South Africa, Australia, and New Zealand. The specification estimated in columns (3) and (4) includes the interaction between TPCI and each one of these variables. The base countries are the ones in Nafta, namely Mexico and Canada. A negative coefficient then indicates that countries in a given region react more negatively to news about partisan conflict over trade than Canada and Mexico do. From the last two columns of Table 8 we learn that Middle East countries are the ones that reduce FDI inflows the most when TPCI rises. The second group that has the most negative reaction is East Asia, as seen by the negative and significant estimated coefficients on the interaction term. The coefficients on America and Other are only statistically significantly different from zero when the $\log$ model is considered (e.g. when the dependent variable is $\ln F D I_{i, t}^{P}$ ), as seen in the last column of the table. 
Table 8: Regression Results, Heterogeneous Effects

\begin{tabular}{|c|c|c|c|c|c|c|}
\hline \multirow[b]{2}{*}{ Dependent Var } & \multicolumn{2}{|c|}{ NAFTA } & \multicolumn{2}{|c|}{ Sub-Regions } & \multicolumn{2}{|c|}{$O E C D$} \\
\hline & $F D I_{i, t}^{P}$ & $\ln F D I_{i, t}^{P}$ & $F D I_{i, t}^{P}$ & $\ln F D I_{i, t}^{P}$ & $F D I_{i, t}^{P}$ & $\ln F D I_{i, t}^{P}$ \\
\hline$T P C I \times N a f t a$ & $\begin{array}{c}0.073^{* *} \\
(0.035)\end{array}$ & $\begin{array}{c}0.101^{* *} \\
(0.042)\end{array}$ & & & & \\
\hline$T P C I \times$ Middle & & & $\begin{array}{c}-0.194^{* *} \\
(0.086)\end{array}$ & $\begin{array}{c}-0.259 * * * \\
(0.095)\end{array}$ & & \\
\hline$T P C I \times E A s i a$ & & & $\begin{array}{c}-0.070^{*} \\
(0.037)\end{array}$ & $\begin{array}{c}-0.138^{*} \\
(0.083)\end{array}$ & & \\
\hline$T P C I \times S E A s i a$ & & & $\begin{array}{l}-0.150 \\
(0.102)\end{array}$ & $\begin{array}{l}-0.087 \\
(0.155)\end{array}$ & & \\
\hline$T P C I \times$ Europe & & & $\begin{array}{l}-0.039 \\
(0.030)\end{array}$ & $\begin{array}{l}-0.045 \\
(0.040)\end{array}$ & & \\
\hline$T P C I \times$ America & & & $\begin{array}{l}-0.066 \\
(0.068)\end{array}$ & $\begin{array}{c}-0.196^{* * *} \\
(0.066)\end{array}$ & & \\
\hline TPCI $\times$ Other & & & $\begin{array}{l}-0.045 \\
(0.030)\end{array}$ & $\begin{array}{c}-0.113^{* *} \\
(0.057)\end{array}$ & & \\
\hline$G D P g r_{i, t}$ & $\begin{array}{l}0.062^{*} \\
(0.035)\end{array}$ & $\begin{array}{c}0.107^{* *} \\
(0.054)\end{array}$ & $\begin{array}{l}0.068^{* *} \\
(0.032)\end{array}$ & $\begin{array}{l}0.127^{* *} \\
(0.051)\end{array}$ & $\begin{array}{l}0.065^{*} \\
(0.036)\end{array}$ & $\begin{array}{c}0.126^{* *} \\
(0.060)\end{array}$ \\
\hline$\Delta F X_{i, t}$ & $\begin{array}{c}1.151^{* * *} \\
(0.101)\end{array}$ & $\begin{array}{c}0.334^{* * *} \\
(0.073)\end{array}$ & $\begin{array}{c}1.113^{* * *} \\
(0.092)\end{array}$ & $\begin{array}{c}0.325^{* * *} \\
(0.067)\end{array}$ & $\begin{array}{c}1.150^{* * *} \\
(0.105)\end{array}$ & $\begin{array}{c}0.376^{* * *} \\
(0.079)\end{array}$ \\
\hline$\pi_{i, t}$ & $\begin{array}{c}0.014 \\
(0.011) \\
(0.011)\end{array}$ & $\begin{array}{c}0.008 \\
(0.008) \\
(0.008)\end{array}$ & $\begin{array}{c}0.020 \\
(0.015) \\
(0.012)\end{array}$ & $\begin{array}{c}0.034^{* * *} \\
(0.011) \\
(0.012)\end{array}$ & $\begin{array}{c}0.019 \\
(0.012) \\
(0.015)\end{array}$ & $\begin{array}{c}0.022^{*} \\
(0.012) \\
(0.011)\end{array}$ \\
\hline$\Delta$ Bilateral $_{i, t}$ & $\begin{array}{c}-0.507^{* *} \\
(0.230)\end{array}$ & $\begin{array}{c}-0.457^{* *} \\
(0.229)\end{array}$ & $\begin{array}{c}-0.495^{* *} \\
(0.244)\end{array}$ & $\begin{array}{c}-0.511^{* *} \\
(0.244)\end{array}$ & $\begin{array}{c}-0.503^{* *} \\
(0.230)\end{array}$ & $\begin{array}{l}-0.470^{*} \\
(0.253)\end{array}$ \\
\hline & $\begin{array}{c}0.064 \\
(0.124)\end{array}$ & $\begin{array}{c}0.124 \\
(0.163)\end{array}$ & $\begin{array}{c}0.063 \\
(0.138)\end{array}$ & $\begin{array}{c}0.113 \\
(0.170)\end{array}$ & $\begin{array}{c}0.067 \\
(0.122)\end{array}$ & $\begin{array}{c}0.131 \\
(0.158)\end{array}$ \\
\hline$T P C I \times N_{o e c d}$ & & & & & $\begin{array}{c}-0.082^{*} \\
(0.043)\end{array}$ & $\begin{array}{c}-0.116^{*} \\
(0.063)\end{array}$ \\
\hline Observations & 1,148 & 1,148 & 1,148 & 1,148 & 1,148 & 1,148 \\
\hline Number of countries & 38 & 38 & 38 & 38 & 38 & 38 \\
\hline R-between & 0.1359 & 0.0125 & 0.2579 & 0.4374 & 0.1331 & 0.1151 \\
\hline R-within & 0.0700 & 0.0652 & 0.0723 & 0.0700 & 0.0712 & 0.0680 \\
\hline
\end{tabular}

Notes: Sample period 1985to 2016, for 38 countries. Robust standard errors, clustered by country, and corrected for autocorrelation are shown in parentheses. Significance denoted as: ${ }^{* * *} \mathrm{p}<0.01,{ }^{* *} \mathrm{p}<0.05,{ }^{*} \mathrm{p}<0.1$

OECD: The final test considers we consider whether emerging countries have a different response to more developed ones. To that end, I construct an interaction term between $N_{\text {oecd }}$ 
which takes a value of 1 if the country does not belong to the OECD and zero otherwise. ${ }^{16}$ This variable is interacted with the TPCI measure. The negative coefficient indicates that non-OECD countries have a stronger response to trade PCI than OECD ones (e.g. increases in TPCI are more detrimental for FDI inflows). On average, a one standard deviation increase in TPCI is associated with a 0.082 standard deviation larger decline in FDI inflows from non-OECD countries. Note that, qualitatively, the effect is the same regardless the functional form used for FDI flows.

Finally, it is worth noticing that the sign and magnitude of the coefficients in other country-specific variables (e.g. $G D P g r_{i, t}, \Delta F X_{i, t}, \pi F X_{i, t}, \Delta$ Bilateral $_{i, t}$, and $\Delta$ Trade $_{i, t}$ ) in Table 8 are consistent across disaggregation models (e.g. Nafta, Sub-regions, and OECD cases), as well as with those in Table 7 .

\section{Conclusion}

This paper analyzed the effects of partisan conflict about trade policy political on foreign direct investment flows to the US. The main departure from existing literature lies on developing and using a novel measure of disagreement about policy that is particularly relevant to foreign investors: the trade partisan conflict index (TPCI). The index tracks the frequency of newspaper articles discussing disagreement about trade policy and international agreements between policymakers. Using aggregate data on investment flows, I find that a one-standard deviation increase in the TPCI results in about 9.8\% decline in FDI flows as a percentage of positions in the country on a given quarter. I also consider FDI flows by parent country, which allows to better control for omitted variable bias and country characteristics, and find a similar response. The results are robust to alternative specifications of the model, such as a log-linear a relationship between FDI and PCI. Finally, I study whether countries in different geographical regions or with different levels of development have heterogeneous responses to increases in TPCI. I find that Canada and Mexico rect less, on average, than other countries and that non-OECD countries tend to have a stronger response to news about trade PCI than OECD countries do.

\footnotetext{
${ }^{16}$ OECD countries are: Austria, Australia, Belgium, Canada, Chile, Denmark, Finland, France, Germany, Hungary, Ireland, Israel, Italy, Luxembourg, Mexico, Netherlands, New Zealand, Norway, Sweden, Spain, Switzerland, and the United Kingdom. Non-OECD countries are: Bahamas, Brazil, Colombia, Hong Kong, Indonesia, Korea, Kuwait, Malaysia, Panama, Philippines, Singapore, South Africa, Taiwan, United Arab Emirates, and Venezuela. Note that the United Arab Emirates joined the OECD at the end of 2014, so we consider it outside of the OECD for the purpose of this study.
} 


\section{References}

[1] Azzimonti, M. 2018. Partisan Conflict and Private Investment. ournal of Monetary Economics, 23, pp 114-131.

[2] Azzimonti, M. 2017. Partisan Conflict, News, and Investors Expectations, mimeo.

[3] Azzimonti, M. and M. Talbert. 2013. Polarized business cycles, Journal of Monetary Economics, 67, 47-61.

[4] Baker, S., Bloom, N. and S. Davis. 2016. Measuring Economic Policy Uncertainty. Quarterly Journal of Economics, 131, 4, pp 1593-1636.

[5] Baker, M., C. Foley, and J. Wurgler. 2009. Multinationals as Arbitrageurs: The Effect of Stock Market Valuations on Foreign Direct Investment. Review of Financial Studies, $22,337-369$.

[6] Basi, R. 1963. Determinants of United States Private Direct Investment in Foreign Countries. Kent State University Press.

[7] Bernanke, B. 1983. Irreversibility, Uncertainty, and Cyclical Investment. Quarterly Journal of Economics, 85106.

[8] Bhattacharya, U., N. Galpin, and B. Haslem. 2007. The Home Court Advantage in International Corporate Litigation, Journal of Law and Economics, 50, 625-659.

[9] Bloom, N. 2009. The Impact of Uncertainty Shocks, Econometrica, 77, 3, 623-685.

[10] Bloom, N., S. Bond, and J. Van Reenen. 2007. Uncertainty and Investment Dynamics. Review of Economic Studies, 74, 391-415.

[11] Busse, M. and C. Hefeker. 2007. Political Risk, Institutions and Foreign Direct Investment. European Journal of Political Economy, 23, 2, 397-415.

[12] Canes-Wrone, C. and J.K. Park. 2011. Electoral business cycles in OECD countries, American Political Science Review, 106, 1, 103-122.

[13] Durnev, A. 2010. The Real Effects of Political Uncertainty: Elections and Investment Sensitivity to Stock Prices. Working paper.

[14] Faeth, I. 2009. Determinants of Foreign Direct Investment - A Tale of Nine Theoretical Mod- els, Journal of Economic Surveys, 23, 165-196.

[15] Fernández-Villaverde, J., and J. Rubio-Ramírez. 2010. Macroeconomics and Volatility: Data, Models, and Estimation, NBER Working Paper No. 16618.

[16] Froot, K., and J. Stein. 1991. Exchange Rates and Foreign Direct Investment: An Imperfect Capital Markets Approach. Quarterly Journal of Economics, 106, 1191-1217. 
[17] Grosse, R. and L. J. Trevino. 1996. Foreign Direct Investment in the United States: An Analysis by Country of Origin, Journal of International Business Studies, 27, 139-155.

[18] Julio, B., and Y. Yook. 2012. Political Uncertainty and Corporate Investment Cycles. Journal of Finance, 67, 4584.

[19] Julio, B. and Y. Yook. 2016. Policy Uncertainty, Irreversibility, and Cross-Border Flows of Capital. Journal of International Economics, 103, pp 13-26.

[20] Klein, M., and E. Rosengren. 1994. The Real Exchange Rate and Foreign Direct Investment in the United States. Journal of International Economics, 36, 373-389.

[21] Li, Q. and A. Resnick. 2003. Reversal of Fortunes: Democratic Institutions and Foreign Direct Investment Inflows to Developing Countries, International Organization, 57, 175211.

[22] Lipsey, R., and M. Weiss. 1984. Foreign Production and Exports of Individual Firms. Review of Economics and Statistics, 66, 304-307.

[23] Loree, D. W. and S. E. Guisinger 1995. Policy and Non-Policy Determinants of U.S. Equity Foreign Direct Investment, Journal of International Business Studies, 26, 281299.

[24] Markusen, J. 1995. The Boundaries of Multinational Enterprises and the Theory of International Trade. Journal of Economic Perspectives, 9, 169-189.

[25] Nordhaus, W. 1975. The Political Business Cycle. Review of Economic Studies, 42, 169190 .

[26] Office of the United States Trade Representative (1986). The President's Trade Policy; an Update. October 8, 1986. Obtained from http://digitalcollections.library.cmu.edu/awweb/awarchive?type=file\&item $=487165$

[27] Pindyck, R., and A. Solimano. 1993. Economic Instability and Aggregate Investment. NBER Macroeconomics Annual, 8, 259-303.

[28] Schneider, F. and B. S.Frey. 1985. Economic and Political Determinants of Foreign Direct Investment. World Development, 13, 161-175.

[29] Rivoli, P. and E. Salorio. 1996. Foreign Direct Investment and Investment under Uncertainty. Journal of International Business Studies, 27, 335-357.

[30] Singh, H., and K. Jun. 1995. Some New Evidence on Determinants of Foreign Direct Investment in Developing Countries. The World Bank Policy Research Working Paper 1531.

[31] Stokey, N. 2016. Wait-and-See: Investment Options under Policy Uncertainty, Review of Economic Dynamics, 21, pp 246-265.

[32] Wei, S. 2000. How Taxing is Corruption on International Investors. Review of Economics and Statistics 82, 1-11. 


\section{Appendix}

\subsection{Sources}

Table 9: Newspaper coverage in Factiva

\begin{tabular}{|c|c|c|c|}
\hline News Source & Start Date & News Source & Start Date \\
\hline The Arizona Republic & Jan-1999 & The New York Times & Jun-1980 \\
\hline The Arkansas Democrat Gazette & Oct-1994 & Newsday & Jul-1985 \\
\hline The Atlanta Journal Constitution & Jan-1986 & The News-Gazette & Mar-2000 \\
\hline The Baltimore Sun & Sept-1990 & The Oklahoman & Nov-1981 \\
\hline Boston Herald & Jul-1991 & Omaha World-Herald & Aug-1983 \\
\hline Buffalo News & Feb-1992 & The Orange County Register & Nov-1986 \\
\hline Charlotte Observer & Jan-1994 & The Oregonian & Jul-1989 \\
\hline Chicago Sun-Times & Jul-1985 & Orlando Sentinel & Oct-1987 \\
\hline Chicago Tribune & Jan-1985 & The Philadelphia Inquirer & Oct-1994 \\
\hline The Christian Science Monitor & Sept-1988 & Pittsburgh Post-Gazette & Jul-1990 \\
\hline The Cincinnati Enquirer & Jan-2002 & The Plain Dealer & Mar-1989 \\
\hline The Columbus Dispatch & Dec-1991 & The Sacramento Bee & Jan-2003 \\
\hline The Boston Globe & Jan-1987 & San Antonio Express-News & Feb-1994 \\
\hline The Courier Journal & Jan-2002 & The San Francisco Chronicle & Apr-2012 \\
\hline The Dallas Morning News & Aug-1984 & San Jose Mercury News & Jan-1994 \\
\hline The Denver Post & Aug-1988 & The Seattle Times & Dec-2008 \\
\hline Detroit Free Press & Jan-1994 & South Florida Sun-Sentinel & Jan-1990 \\
\hline The Detroit News & Jan-2002 & St. Louis Post-Dispatch & Jan-1992 \\
\hline The Fort Worth Star-Telegram & Jun-2001 & St. Paul Pioneer Press & Jan-1994 \\
\hline The Hartford Courant & May-1991 & The Star-Ledger & Jan-1991 \\
\hline Houston Chronicle & Apr-2012 & Star-Tribune & Jan-1986 \\
\hline Indianapolis Star & Jan-2002 & Tampa Bay Times & Nov-1986 \\
\hline Investor's Business Daily & Jan-2002 & Tampa Tribune & Jul-2011 \\
\hline The Kansas City Star & Jan-1991 & The Times-Picayune & Apr-1992 \\
\hline Los Angeles Times & Jan-1985 & USA Today & Apr-1987 \\
\hline The Miami Herald & Oct-1994 & U-T San Diego & Jan-2000 \\
\hline The Milwaukee Journal Sentinel & Jan-2000 & The Wall Street Journal & Jun-1979 \\
\hline New York Daily News & Dec-1992 & The Washington Post & Jan-1984 \\
\hline New York Post & Sept-1997 & Washington Post.com & Oct-2007 \\
\hline
\end{tabular}

Note: This table contains the names of the main US newspapers used in constructing the Partisan Conflict Index: Trade, together with the coverage start month in Factiva's database. 


\subsection{Filters}

$\begin{array}{llll}\text { NADVTR } & \text { Advertorials } & \text { GLIFE } & \text { Lifestyle } \\ \text { NEDC } & \text { Commentary/opinion } & \text { GROYAL } & \text { Royal Family } \\ \text { NCOPRO } & \text { Country Profile } & \text { GCOM } & \text { Society/Community/Work } \\ \text { NEDI } & \text { Editorial } & \text { GWEA } & \text { Weather } \\ \text { NITV } & \text { Tv listings } & \text { NRGN } & \text { Routine general news } \\ \text { NLET } & \text { Letters } & \text { E52 } & \text { Eurozone currency news } \\ \text { NOBT } & \text { Obituaries } & \text { GRAPE } & \text { Rape } \\ \text { NPEO } & \text { People profiles } & \text { GJURI } & \text { Juri } \\ \text { NPAN } & \text { Personal announcements } & \text { gdoga } & \text { Dog attacks } \\ \text { NRAN } & \text { Rankings } & \text { gdomv } & \text { Domestic violence } \\ \text { NRVW } & \text { Reviews } & \text { ghara } & \text { Harrassment } \\ \text { GSPO } & \text { Sports } & \text { gprob } & \text { Probation } \\ \text { GENT } & \text { Entertainment } & \text { gtrff } & \text { Traffic violations } \\ \text { GAWARD } & \text { Awards/Lotteries } & \text { gvand } & \text { Vandalism } \\ \text { GHEA } & \text { Health } & & \end{array}$

I exclude editorials and commentaries from the search in an attempt to reduce potential ideological biases (see the work by Gentzkow and Shapiro, 2010, on media slant). In addition, news items are restricted to at least 200 words. Finally, articles re-printed in several newspapers are eliminated to minimize double-counting. 


\subsection{Sample article}

Los Angeles Times | aRticle coulections

$\leftarrow$ Back to Original Article

House Passes NAFTA, 234-200 : Clinton Hails Vote as Decision 'Not to Retreat' : Congress: Sometimes bitter debate over the trade pact reflects hard-fought battle among divided Democrats. Rapid approval is expected in the Senate.

November 18, 1993 | JAMES GERSTENZANG and MICHAEL ROSS I TIMES STAFF WRITERS

WASHINGTON - A painfully divided House of Representatives approved the North American Free Trade Agreement by an unexpectedly large margin Wednesday night, ending a hard-fought battle that grew into a referendum on the fundamental changes sweeping the American economy.

The vote was 234 to 200,16 more than the 218 needed for passage. The Senate is expected to act on the measure within days. Passage there is not in doubt.

In a brief appearance in the White House grand foyer less than an hour after the vote, a beaming President Clinton savored the come-from-behind victory and declared: "Tonight's vote is a defining moment. At a time when many of our people are hurting ... we chose to compete and not to retreat."

The strongest support in the House came from Republicans, who cast 132 votes for the trade plan and 43 against it. Among Democrats, 102 voted for the agreement and 156 opposed it. The one independent in Congress voted against the plan.

"It is not a perfect agreement," said House Speaker Thomas S. Foley (D-Wash.) in an address to his colleagues. "But this is, for the moment, an opportunity to expand our trade, to reach out beyond our borders ... to seize the future."

"Is it good for America or not? I believe passionately it is good for America," he said.

Reflecting the division that the plan has generated, his two most senior deputies, House Majority Leader Richard A. Gephardt of Missouri and House Majority Whip David E. Bonior of Michigan, opposed the agreement.

"It will cost jobs. It will drive down our standard of living. It will lock in place a Mexican system that exploits its own people and denies them the most basic political and economic rights," Bonior said.

Expanding on a 5-year-old, U.S.-Canadian free-trade pact, the agreement would eliminate most tariffs, quotas and other barriers to unrestrained commerce among the United States, Mexico and Canada over a 15-year period, beginning Jan. 1, 1994.

The agreement would remove most tariffs now levied on Mexican goods entering the United States, such as the $15 \%$ surcharge slapped on electronic components manufactured south of the border. As a result, U.S. companies and their workers will be forced to compete with Mexican firms paying wages that in some cases are as little as one-tenth those paid here.

On the other side of the equation, most Mexican tariffs assessed on U.S. products would be eliminated. For example, U.S. chemical manufacturers, which now pay similar tariffs when they ship their goods to Mexico, say they expect sales to expand well beyond last year's $\$ 3$ billion once the pact takes effect, giving them a competitive edge over overseas chemical concerns. U.S. firms that make other products now subject to Mexican tariffs anticipate similar benefits.

The Clinton Administration has argued that the net effect of such trade-offs, with tariffs disappearing on thousands of products, will help lift Mexico out of the economic rut in which it has been stuck for generations. The jobs created by an expanding Mexican economy, in turn, will fuel the growth of a booming consumer market anxious to purchase the products of U.S. factories, the Administration contends.

Despite the emotion that has enveloped the issue across the nation, much of the debate on Wednesday--save for the final arguments--contained little passion. The debate began at 9 a.m. and continued for approximately 13 hours.

All told, 245 representatives-an astoundingly high number--trooped to the well of the House to speak. But with the results not in doubt, they spoke not so much to influence their colleagues as to explain their votes to political supporters at home.

The House vote was widely regarded as a key test of Clinton's legislative acumen. A loss would have cast doubt on his ability to shepherd other Administration initiatives through Congress and weakened his hand in dealings with foreign leaders. The victory gives new momentum to his ambitious domestic agenda and pending trade talks with other nations.

Perhaps more important, the verdict is expected to send a strong signal of U.S. willingness to continue exercising leadership in world affairs. Some supporters argued that a rejection would have heralded a dangerous new era of isolation and protectionism.

"A vote against NAFTA is a vote for economic surrender," declared House Ways and Means Committee Chairman Dan Rostenkowski (D-Ill.), one of the Administration's key allies in the congressional leadership.

If the emotion of the debate was dissipated, it was replaced by a palpable bitterness as dejected opponents angrily accused colleagues of selling their votes in exchange for promises of political support or pork-barrel rewards.

"The wounds are pretty deep, and it will take time and work to heal them" House Deputy Whip Bill Richardson (D-N.M.) said after the vote.

\subsection{Variables and Sources for US Data}

Annual data ranging from 1981 to 2016 unless otherwise noted.

- FDI 
- FDIUS: Foreign direct investment in U.S. (Flow) from the rest of the world. In millions of dollars, seasonally adjusted (annual rate). Source: Board of Governors of the Federal Reserve System (US). Series id: ROWFDIQ027S. Data retrieved from ALFRED, Federal Reserve Bank of St. Louis

https://alfred.stlouisfed.org/series?seid=ROWFDIQ027S.

- Position: Foreign direct investment in U.S. (Levels) from the rest of the world. In millions of dollars, quarterly, not seasonally adjusted. Source: Board of Governors of the Federal Reserve System (US). Series id: ROWFDNQ027S. Data retrieved from ALFRED, Federal Reserve Bank of St. Louis https://alfred.stlouisfed.org/series?seid=ROWFDNQ027S.

- $F D I_{t}^{P}$ : FDIUS scaled by the cumulative FDI position in the US at the end of the previous period $t-1$.

$$
F D I_{t}^{P}=\frac{F D I U S_{t}}{\text { Position }_{t-1}}
$$

- U.S. Direct Investment Abroad: Rest of the world; U.S. direct investment abroad, including Netherlands Antillean Financial subsidiaries; liability (Levels). In millions of dollars, quarterly, not seasonally adjusted Foreign direct investment in U.S. Source: Board of Governors of the Federal Reserve System (US). Series id: ROWDIAQ027S. Data retrieved from ALFRED, Federal Reserve Bank of St. Louis https://alfred.stlouisfed.org/series?seid=ROWDIAQ027S.

- Political Indicators

- PCI: Partisan Conflict Index (PCI).

Data retrieved from Federal Reserve Bank of Philadelphia https://www.philadelphiafed.org/researchand-data/real-time-center/partisan-conflict-index.

- TPCI: Trade Partisan Conflict Index. Computed by author.

- PE: Indicator variable which equals 1 when there is a Presidential election in the US and 0 otherwise.

- EPU: Economic Policy Uncertainty Index. Baseline overall index for the US Monthly. This series is available from 1985 to 2016. Data retrieved from http://www.policyuncertainty.com/us-monthly.html

- Trade

- $M$ : Imports of Goods \& Services. In billions of dollars, seasonally adjusted (annual rate). Source: ALFRED, Federal Reserve Bank of St. Louis. Series id: IMPGS. Data retrieved from https://alfred.stlouisfed.org/series?seid=IMPGS. 
- $X$ : Exports of Goods \& Services. In billions of dollars, seasonally adjusted (annual rate). Source: ALFRED, Federal Reserve Bank of St. Louis. Series id: EXPGS. Data retrieved from

https://alfred.stlouisfed.org/series?seid=EXPGS.

- Trade: Sum of exports $X$ and imports $M$ scaled by GDP,

$$
\text { Trade }=\frac{X+M}{G D P}
$$

- Prices and rates

- FX: Exchange rates, Trade Weighted U.S. Dollar Index: Major Currencies, Index Mar 1973=100, Quarterly, Not Seasonally Adjusted. Source: ALFRED, Federal Reserve Bank of St. Louis. Series id: DTWEXM. Data retrieved from https://alfred.stlouisfed.org/series?seid=DTWEXM.

- FF: Effective Federal Funds Rate, Percent, Quarterly, Not Seasonally Adjusted. Source: ALFRED, Federal Reserve Bank of St. Louis. Series id: FF. Data retrieved from

https://fred.stlouisfed.org/series/FF.

$-\pi$ : Inflation, Consumer Price Index for All Urban Consumers: All Items, Percent Change, Seasonally Adjusted. Source: ALFRED, Federal Reserve Bank of St. Louis. Series id: CPIAUCSL_PCH. Data retrieved from

https://alfred.stlouisfed.org/series?seid=CPIAUCSL_PCH.

- Economic indicators

- GDP: Gross Domestic Product. In billions of current dollars, quarterly, seasonally adjusted. Source: ALFRED, Federal Reserve Bank of St. Louis. Series id: GDP. Data retrieved from

https://fred.stlouisfed.org/series/GDP

- GDP $P_{r}$ Real Gross Domestic Product. In billions of chained 2009 dollars, quarterly, seasonally adjusted. Source: ALFRED, Federal Reserve Bank of St. Louis. Series id: GDP. Data retrieved from

https://fred.stlouisfed.org/series/GDPC1

- GDP $P_{p}$ : Real Potential Gross Domestic Product. In billions of chained 2009 dollars, quarterly, not seasonally adjusted. Source: ALFRED, Federal Reserve Bank of St. Louis. Series id: GDP. Data retrieved from https://fred.stlouisfed.org/series/GDPPOT

- GAP: Output gap, computed as the difference between real GDP and potential real GDP.

$$
G A P=G D P_{r}-G D P_{p}
$$


- GDP $P_{r}$ : US GDP growth. Corresponds to Real Gross Domestic Product, Percent Change from Quarter One Year Ago, Quarterly, Seasonally Adjusted. Source: ALFRED, Federal Reserve Bank of St. Louis. Series id: A191RO1Q156NBEA. Data retrieved from https://fred.stlouisfed.org/series/A191RO1Q156NBEA

- Sentiment: Consumer confidence index in the United States, constructed by the University of Michigan. Source: ALFRED, Federal Reserve Bank of St. Louis. Series id: UMCSENT. Data retrieved from https://fred.stlouisfed.org/series/UMCSENT

- Leading: Leading Index for the United States, computed by the Federal Reserve Bank of Philadelphia's Survey of Professional Forecasters. Series in percentage terms, seasonally adjusted. Source: ALFRED, Federal Reserve Bank of St. Louis. Series id: USSLIND. Data retrieved from

https://fred.stlouisfed.org/series/USSLIND

- Unemployment: Unemployment Rate in the United States: 20 years and over, Percent, Seasonally Adjusted. Source: ALFRED, Federal Reserve Bank of St. Louis. Series id: LNS14000024. Data retrieved from

https://fred.stlouisfed.org/series/LNS14000024

\subsection{Additional Variables and Sources for Panel Data}

Annual data ranging from 1985 to 2016.

- FDI

- FDIU $S_{i, t}$ : Foreign direct investment in U.S. (Flow) from country $i$, in million of dollars, on year $t$. Source: Bureau of Economic Analysis, under 'Foreign Direct Investment in the U.S.: Balance of Payments and Direct Investment Position Data, Financial transactions without current-cost adjustment.' Data retrieved from http://www.bea.gov/international/dilfdibal.htm

- Position ${ }_{t}^{i \rightarrow U S}$ : Foreign direct investment in U.S. (Stock) from country $i$, in millions of US dollars. Source: Bureau of Economic Analysis, Country Detail, under 'Foreign Direct Investment in the United States: Selected Items by Detailed Country, Position on a Historical-Cost Basis.' Data retrieved from http://www.bea.gov/international/dilfdibal.htm

- $\ln F D I_{i, t}^{P}$ : Busse and Hefeker log transformation of FDI flows

$$
\ln F D I_{i, t}^{P}=\ln \left(F D I_{i, t}^{P}+\sqrt{\left(F D I_{i, t}^{P}\right)^{2}+1}\right)
$$


- FDI $I_{i, t}^{P}$ : Average FDI inflows from country $i$ as a ratio of the (lagged) stock of FDI from country $i$ in the US.

$$
F D I_{i, t}^{P}=\frac{F D I U S_{t}}{\text { Position }_{t-1}^{i \rightarrow U S}}
$$

- Trade

- $M_{i, t}$ : Imports of Goods \& Services from the rest of the world to country $i$. Expressed in millions of US dollars, seasonally adjusted. Source: World Bank and Global Financial Data.

- $X_{i, t}$ : Exports Imports of Goods \& Services from country $i$ to the rest of the world. Expressed in millions of US dollars, seasonally adjusted. Source: World Bank and Global Financial Data.

- Trade $_{i, t}$ : Sum of country $i$ 's total exports $X_{i, t}$ and imports $M_{i, t}$ scaled by GDP of country $i$ in year $t$,

$$
\text { Trade }_{i, t}=\frac{X_{i, t}+M_{i, t}}{G D P_{i, t}}
$$

- Bilateral Trade ${ }_{i, t}$ : Sum of US exports to country $i X_{i, t}^{U S}$ to $i$ and US imports from $i, M_{i, t}^{U S}$ scaled by GDP of country $i$ in year $t$.

$$
\text { Bilateral Trade }_{i, t}=\frac{X_{i, t}^{U S}+M_{i, t}^{U S}}{G D P_{i, t}}
$$

Imports and exports in millions of U.S. dollars on a nominal basis, not seasonally adjusted.

Obtained from the US Census, Table U.S. 'Trade in Goods by Country' https://www.census.gov/foreigntrade/balance/index.html

- Prices and rates

- FX $X_{i, t}$ : Exchange rates, Country $i$ National Currency per U.S. dollar. Retrieved from Global Financial Data, using market price quotes.

- $\pi_{i, t}$ : Inflation of country $i$. Percentage change in average consumer prices (Index). Source: World Economic Outlook Database. Series id: PCPIPCH. Data retrieved from

https://www.imf.org/external/pubs/ft/weo/2017/02/weodata/index.aspx

- Economic indicators 
- GDP $i, t$ : Nominal GDP of country $i$ in millions US dollars. The Gross Domestic Product at current prices from National Account Aggregates is retrieved from Global Financial Data, in millions of National Currency, and converted to US dollars using the exchange rate $F X_{i}$. Series annualized when available only as quarterly flows.

- GDPgr ${ }_{i, t}$ : GDP growth of country $i$. Percent change in Gross Domestic Product, at constant prices. Annual percentages of constant price GDP are year-onyear changes; the base year is country-specific. Source: World Economic Outlook Database. Series id: NGDP_RPCH. Data retrieved from

https://www.imf.org/external/pubs/ft/weo/2017/02/weodata/index.aspx

\subsection{Alternative specifications}

Table 10 includes growth in the unemployment rate, $\Delta U_{t}$, instead of the growth rate of real GDP in order to control for aggregate economic conditions in the US. We can see that the sign and magnitude of the coefficients is basically unchanged for the main variable of interest, as well as other controls. As expected, higher unemployment growth deters FDI inflows as seen by the negative coefficient throughout all specifications. 
Table 10: Summary statistics of quarterly FDI measures

\begin{tabular}{|c|c|c|c|c|c|}
\hline \multirow[t]{2}{*}{ Dependent Var } & \multicolumn{4}{|c|}{ Flow/Position } & \multirow{2}{*}{$\begin{array}{c}\text { Busse-Hefeker } \\
(5)\end{array}$} \\
\hline & (1) & $(2)$ & (3) & (4) & \\
\hline$T P C I_{t}$ & $\begin{array}{c}-0.042^{* *} \\
(0.017)\end{array}$ & $\begin{array}{c}-0.039^{* *} \\
(0.016)\end{array}$ & $\begin{array}{c}-0.038^{* *} \\
(0.016)\end{array}$ & $\begin{array}{c}-0.047^{* *} \\
(0.021)\end{array}$ & $\begin{array}{c}-0.078^{* *} \\
(0.030)\end{array}$ \\
\hline$G D P g r_{i, t}$ & $\begin{array}{c}0.085^{* *} \\
(0.042)\end{array}$ & $\begin{array}{l}0.084^{*} \\
(0.042)\end{array}$ & $\begin{array}{l}0.082^{*} \\
(0.040)\end{array}$ & $\begin{array}{l}0.083^{*} \\
(0.041)\end{array}$ & $\begin{array}{c}0.131^{* *} \\
(0.055)\end{array}$ \\
\hline$\Delta F X_{i, t}$ & $\begin{array}{c}1.177^{* * *} \\
(0.060)\end{array}$ & $\begin{array}{c}1.181^{* * *} \\
(0.055)\end{array}$ & $\begin{array}{c}1.191^{* * *} \\
(0.057)\end{array}$ & $\begin{array}{c}1.192^{* * *} \\
(0.058)\end{array}$ & $\begin{array}{c}0.358^{* * *} \\
(0.070)\end{array}$ \\
\hline$\pi_{i, t}$ & $\begin{array}{c}0.013^{* *} \\
(0.006)\end{array}$ & $\begin{array}{c}0.013^{* *} \\
(0.006)\end{array}$ & $\begin{array}{c}0.013^{* *} \\
(0.006)\end{array}$ & $\begin{array}{c}0.013^{* *} \\
(0.006)\end{array}$ & $\begin{array}{l}0.014^{* *} \\
(0.006)\end{array}$ \\
\hline$\Delta$ Bilateral $_{i, t}$ & $\begin{array}{c}-0.406^{* *} \\
(0.184)\end{array}$ & $\begin{array}{c}-0.408^{* *} \\
(0.186)\end{array}$ & $\begin{array}{c}-0.416^{* *} \\
(0.192)\end{array}$ & $\begin{array}{c}-0.399^{* *} \\
(0.194)\end{array}$ & $\begin{array}{l}-0.319 \\
(0.250)\end{array}$ \\
\hline$\Delta$ Trade $_{i, t}$ & $\begin{array}{l}-0.082 \\
(0.076)\end{array}$ & $\begin{array}{l}-0.091 \\
(0.075)\end{array}$ & $\begin{array}{l}-0.080 \\
(0.070)\end{array}$ & $\begin{array}{l}-0.076 \\
(0.079)\end{array}$ & $\begin{array}{l}-0.091 \\
(0.132)\end{array}$ \\
\hline$\Delta U_{t}$ & $\begin{array}{c}-0.075^{* *} \\
(0.035)\end{array}$ & $\begin{array}{l}-0.116^{*} \\
(0.063)\end{array}$ & $\begin{array}{l}-0.119^{*} \\
(0.063)\end{array}$ & $\begin{array}{c}-0.158^{* *} \\
(0.075)\end{array}$ & $\begin{array}{l}-0.177^{*} \\
(0.089)\end{array}$ \\
\hline$G A P_{t}$ & $\begin{array}{l}-0.004 \\
(0.041)\end{array}$ & $\begin{array}{l}-0.027 \\
(0.035)\end{array}$ & $\begin{array}{l}-0.110^{*} \\
(0.063)\end{array}$ & $\begin{array}{l}-0.070 \\
(0.063)\end{array}$ & $\begin{array}{l}0.005 \\
(0.072)\end{array}$ \\
\hline$\pi_{t}$ & $\begin{array}{l}-0.044 \\
(0.034)\end{array}$ & $\begin{array}{l}-0.050 \\
(0.038)\end{array}$ & $\begin{array}{l}-0.042 \\
(0.037)\end{array}$ & $\begin{array}{l}-0.082^{*} \\
(0.045)\end{array}$ & $\begin{array}{l}-0.097 \\
(0.063)\end{array}$ \\
\hline$F F_{t}$ & $\begin{array}{c}0.020 \\
(0.039)\end{array}$ & $\begin{array}{c}0.019 \\
(0.039)\end{array}$ & $\begin{array}{c}0.041 \\
(0.042)\end{array}$ & $\begin{array}{c}0.071 \\
(0.043)\end{array}$ & $\begin{array}{c}0.101 \\
(0.074)\end{array}$ \\
\hline$P C I_{t}$ & & $\begin{array}{l}-0.035 \\
(0.049)\end{array}$ & $\begin{array}{l}-0.011 \\
(0.054)\end{array}$ & $\begin{array}{l}-0.025 \\
(0.055)\end{array}$ & $\begin{array}{l}-0.055 \\
(0.052)\end{array}$ \\
\hline$E P U_{t}$ & & & $\begin{array}{c}-0.094^{* *} \\
(0.046)\end{array}$ & $\begin{array}{c}-0.098^{* *} \\
(0.047)\end{array}$ & $\begin{array}{l}-0.043 \\
(0.056)\end{array}$ \\
\hline Sentiment $_{t}$ & & & & $\begin{array}{l}-0.077 \\
(0.069)\end{array}$ & $\begin{array}{l}-0.124^{*} \\
(0.073)\end{array}$ \\
\hline Leading $_{t}$ & & & & $\begin{array}{l}-0.034 \\
(0.042)\end{array}$ & $\begin{array}{l}-0.043 \\
(0.050)\end{array}$ \\
\hline Observations & 1,148 & 1,148 & 1,148 & 1,148 & 1,148 \\
\hline R-squared & 0.037 & 0.038 & 0.040 & 0.042 & 0.028 \\
\hline Number of countries & 38 & 38 & 38 & 38 & 38 \\
\hline
\end{tabular}

Notes: Sample period 1985to 2016, for 38 countries. Robust standard errors, clustered by country, and corrected for autocorrelation are shown in parentheses. Significance denoted as: $* * * \mathrm{p}<0.01, * * \mathrm{p}<0.05, * \mathrm{p}<0.1$ 